IZA DP No. 10338

Do Leaders' Characteristics and Regime Transitions in Africa Matter for Citizens' Health Status?

Luis Diaz-Serrano

Frank G. Sackey

October 2016 


\title{
Do Leaders' Characteristics and Regime Transitions in Africa Matter for Citizens' Health Status?
}

\author{
Luis Diaz-Serrano \\ CREIP, Universitat Rovira i Virgili \\ and IZA \\ Frank G. Sackey \\ CREIP, Universitat Rovira i Virgili
}
Discussion Paper No. 10338
October 2016

\author{
IZA \\ P.O. Box 7240 \\ 53072 Bonn \\ Germany \\ Phone: +49-228-3894-0 \\ Fax: +49-228-3894-180 \\ E-mail: iza@iza.org
}

\begin{abstract}
Any opinions expressed here are those of the author(s) and not those of IZA. Research published in this series may include views on policy, but the institute itself takes no institutional policy positions. The IZA research network is committed to the IZA Guiding Principles of Research Integrity.

The Institute for the Study of Labor (IZA) in Bonn is a local and virtual international research center and a place of communication between science, politics and business. IZA is an independent nonprofit organization supported by Deutsche Post Foundation. The center is associated with the University of Bonn and offers a stimulating research environment through its international network, workshops and conferences, data service, project support, research visits and doctoral program. IZA engages in (i) original and internationally competitive research in all fields of labor economics, (ii) development of policy concepts, and (iii) dissemination of research results and concepts to the interested public.
\end{abstract}

IZA Discussion Papers often represent preliminary work and are circulated to encourage discussion. Citation of such a paper should account for its provisional character. A revised version may be available directly from the author. 


\title{
ABSTRACT \\ Do Leaders' Characteristics and Regime Transitions in Africa Matter for Citizens' Health Status?*
}

\begin{abstract}
Africa's quest to achieving improved health status and meeting the Millennium Development Goals targets cannot be effectively achieved without examining the quality of leadership, transitions and regimes and how they impact on the decisions and the policy effectiveness that bring about improved health and living standards of the citizenry. In this paper, we study the importance of leader characteristics and regime transitions on government's expenditure in health, and hence on infant mortality, as a development indicator. A unique dataset comprising 44 sub-Saharan African countries spanning from 1970 to 2010 was used for the study. To effectively analyze the impact of leader characteristics and regime transitions on the citizens' health status we control for leader fixed-effects since different leaders, among other things impact on outcomes differently and changes in policy to a large extent depend on the leader characteristics. The overall results are suggestive of a democratic advantage in the process of achieving effective health policy outcomes for promoting health and the wellbeing of the citizens in contemporary sub-Saharan Africa, at least in the long run. Whilst there is evidence of more private and public investments in the health sector under democratic leadership, Government's health policy is virtually non-existent under dictatorships and public sector investment in the health sector is on the decadence.
\end{abstract}

JEL Classification: I15, H51, O55

Keywords: Africa, health policy, public health, private health, child mortality, democracy, autocracy, political leaders

Corresponding author:

Luis Diaz-Serrano

Department of Economics

Universitat Rovira i Virgili

Av. Universitat 1

43204 Reus

Spain

E-mail: luis.diaz@urv.cat

\footnotetext{
* We acknowledge financial support from the Ministry of Economy and Competitiveness grant \#ECO2014-59055-R.
} 


\section{Introduction}

There is an increasing recognition that health creates wealth and advances GDP. Africa has made significant strides in certain areas of socio-economic development; however, there is the potential to achieve more if it can overcome the large burden of diseases which continue to be a barrier to faster development. It is estimated that for every $10 \%$ increase in life expectancy at birth there is a corresponding rise in economic growth of $0.4 \%$ and this in turn leads to a further rise in life expectancy at birth (WHO, 2014). According to Deaton (2003), increases in growth leads to increases in incomes which in turn cause good health. Gupta and Mitra (2004) observe that growth tends to reduce poverty and improves health status. They also observe that growth and health status are positively correlated and have a two-way relationship, suggesting that better health enhances growth by improving productivity and higher growth allows better human capital formation.

Significant progress is being made in achieving many of the millennium development goals; Average overall incomes have increased by 20\% between 1990 and 2002. Child mortality rates fell from 103 deaths per 1000 live births to 88 in 2002 and a further decrease to 43 in 2015 (UN, 2015). In Sub-Saharan Africa the annual rate of this reduction was over five times faster during 2005-2013 than it was during 1990-1995 though not uniform across countries. There are huge disparities as the progress has been far from uniform across countries and across the goals. Sub-Sahara Africa is the epicenter of crisis, with continuing food insecurity, high child and maternal mortality, a rise in extreme poverty and a wide spread shortfall for most of the Millennium Development Goals (MDGs) (UN, 2015). Africa is still not on track to meeting the health Millennium Declaration targets. The maternal mortality rate will need to drop from between 500 and 1500 to 228 per 100,000 and under 5 years old mortality from 171 to 61 per

1000 to reach the respective Millennium Development Goals. Women and Children carry a 
disproportionate share of Africa's heavy disease burden, with 4.8 million children dying annually from preventable diseases.

Whether explicit or implicit, a vision of improved and access to health facilities must be embedded in the country's policies and programmes and these are largely influenced by the leader's interest, initiatives and commitments. Quality health that ensures quality human capital for sustainable and accelerated growth largely depends on the quality of leadership. According to Jones and Olken (2005), quality leadership matters for economic growth as individual leaders play significant role in accelerating overall economic development. The quality of leadership is enhanced through education, honesty, responsibility, commitment, etc. Our research examines the extent to which African leaders' characteristics and regime transitions impact on the citizens' health status conditioned on growth. It also examines the extent to which leader characteristics and regime transitions influence health policies through the allocation of resources to the health sector. We are doing this because the policy direction of every nation and therefore the growth and development of that nation at any point in time depends largely on the leadership qualities of its ruler and the political regime of the country.

Recent literature on the relationship between regime and growth suggests that the relationship may well be different across regions of the world (Krieckhaus, 2006), due to historical factors. Econometric analyses of Africa's growth strategy in the 1970s and 1980s have largely ignored regime-transition variables as (Easterly and Levine, 1997) focused on ethnic fragmentation; (Englebert, 2000) on artificial nature of African state borders; (Sachs and Warner,1997) on geographical characteristics of the region and (Bates, 1981) on power of urban interest groups, with the exception of (Ndulu and O'connel, 1999) who attributes the phenomenon on the authoritarian nature of most of its rulers and( Masaki and van de Walle, 2014) who find a strong evidence that democracy promotes growth in Africa. The only research close to ours is that of Jorgensen and Bjornskov (2015) who considered both leader 
characteristics and transitions but only with first African leaders. Our paper is different in that we combine both leader characteristics and regime transitions in examining their effects on health status conditioned on growth as an indicator of economic wellbeing. An annual infant mortality rate was chosen as the health indicator over the other health indicators due to the fact that it takes relatively less time to react to health policy changes than other indicators as life expectancy. Thus, a leader who immediately implements effective health policies is likely to observe a reduction in the infant mortality rate the following few years, unlike life expectancy that may take relatively longer period.

In our empirical model, we control for leader specific effects instead of country specific effects due to the following reasons; changes in policy may not only be due to changes in political regime transitions but also depend on the characteristics of the leader; leaders vary significantly and therefore different leaders will impact on outcomes differently; leaders matter more in certain regimes as they have fewer constraints on the power that they exert according to Jones and Olken (2005). Since one leader can be in office only in one country, the leaderspecific effects also absorb the country specific effects. We test for the impact of leader characteristics and political regime transitions from an autocratic leader to a democratic leader and from a democratic leader to an autocratic leader on infant mortality to examine which transition and type of leaders in the African perspective have a desirable effect on the health of the citizens.

According to Jones and Olken (2005), Dreher et al (2009) Besley and Reynol-Querol (2011), Jong-A- Pin and Mierau (2013) or Diaz-Serrano and Perez-Reynosa (2013), leaders matter for ensuring growth since more competent leaders are more likely to make better policy choices that enhance economic development and human capital. This assertion to them comes from the assumption that quality leaders are more likely to act in the public interest, society's aspirations and goals. In the case of post-independent Africa, the leaders in many cases 
determine and influence the rules of the game and the abilities and choices of the leader have greater influence on how resources are distributed. Sub-Saharan Africa remains poorest in the world as a consequence of 20 years of declining GDP, from a massive decline in 1972 until the 1990s and 2000s when many of these countries embraced democracy (Paldam, 2013).

Additionally, the literature considers the barriers for institutional reforms, policy interventions and implementations and in this; emphasis is put on shocks including transitions which can also open up for these barriers (Bjornskov and Potrafke, 2011; Diaz-Serrano and Perez-Reynosa, 2013; Jorgensen and Bjornskov, 2015). The question we would like to find answers to is whether the window of opportunity created by transition from one regime to another impacts positively on citizen's health status conditioned on growth and leader characteristics. If the standard of living of citizens, measured by GDP, health status and education depends to a large extent, on the quality of leadership, then we should be able to observe differences in a variety of outcomes that occur under their stewardship by holistically looking at the various factors that constitute the characteristics or the personality of the leader. These will be tested empirically with a panel data set consisting of observation from African countries between 1970 and 2010.

We observe that transitions from an autocratic leader to a democratic leader, reduces infant mortality and increases public health expenditure. When this particular transition prevails over a longer period there is continuous reduction in infant mortality and public health expenditure is increased. In the case of a transition from a democratic leader to an autocratic leader, infant mortality rate increases and there is reduction in public sector investments in health, while the investment in private health grows significantly. Infant mortality growth rate continues increasing when such transition prevails for a longer period.

This paper contributes to the burgeoning literature with the view that the health needs and the development of Africa, to a large extent, depends on the leadership characteristics of its 
leaders and regime. What makes post-independence sub-Saharan Africa so interesting is that they have witnessed all forms of transitions, from democratic regime to dictatorship and viceversa. All these have possibilities of changing and creating new institutions and policies that affect the quality of life of the citizens in their respective countries.

With the aim described above, this chapter has been structured as follows. In section 2 we begin an overview of the literature on leadership qualities with emphasis on the African leadership and health perspective, good governance policy and health and the effects of leader characteristics, regimes and transitions on policy outcomes especially on growth and health. Section 3 discusses the framework of our hypothesis testing; section 4 focusses on the data used for the study and the description of the variables used for the study. Section 5 reports on the specification of the empirical model and the discussions of the results and finally section 6 , on the conclusion.

\section{Theoretical literature}

A body of literature has focused on explaining factors determining growth as well as development, and in line with this paper, we discuss a selection of the potential determinants in the literature and the literature imposing that the quality of the institutions as well as its leaders are the underlying factors when it comes to poor growth and development.

Various theories have explained the selection of leaders as means of achieving societal aspirations and goals. One of such theories is the citizen-candidate type as explained by Osborne and Slivinski (1996) and Besley et al (1997). They see political competition and selection as a game between people competing to hold office where with limited commitment, selection based on policy preferences, talent or virtue can affect policy outcomes. This theory has motivated the studies on effects of political reservation that is, reserving political office for particular groups in society, and argues that reservation matters by changing the identities of those elected into 
office (Pande, 2003; Duflo, 2004). Lee et al (2004), using US data on close elections also argue that political affiliations matter.

Another theory, the quality based in political selection has been propounded in a citizencandidate framework by Caselli and Massimo (2002) and Poutvarra and Thomas (2003). Caselli and Massimo (2002) explain that the supply and selection of bad politicians exist and the factors that explain such supply include rents that such politicians earn whilst in office and the existence of imperfect information that make it difficult to spot candidate quality. Poutvarra and Thomas (2003) also develop a model in which the value of holding office impacts on the candidate quality through its effects of election campaigns. Cross country empirical studies have found evidence showing that more competitive election often increase government responsiveness in terms of providing more public goods and services (Brown and Wendy, 2004; Lake and Baum, 2001).

We base our study on (Jones and Olken, 2005; Besley and Reynol-Querol, 2011 and Diaz Serrano and Perez Reynosa, 2013) who show that the quality of leaders matters for growth and human capital, with emphasis on African leaders. Our study will contribute to literature in that our empirical evidence will explain the mechanism for this assertion. There is the suggestion that some leaders may be more inclined to influence policy on the provision of public goods and other social capital which have wide range of economic benefits. There is also the view that some leaders are more competent and effective than others and more able to make rational and economic policy choices which enhance economic development. In relation to this is the possibility that some leaders focus on broad based economic objectives rather than promoting narrow sectional interest which favor protectionist policies. In all of the above the returns to having a good leader comes from the assumption that good leaders are also better citizens who will promote policies that will better the lots of its citizens and therefore more likely to operate in the broader public interest. According to Kodila-Tedika (2014), if indeed, all quality leaders 
productively use their intelligence in the economy, chances are that society will benefit from a more productive labor force at all levels of governance, state or local. This in turn allows society to take advantage of being able to mimic the positive experiences of successful nations, including the area of governance as well as the advantages of imitations and innovation predicted in the theories of endogenous growth (Aghion and Howitt, 2009), which in turn leads to a virtuous cycle of development of which improvement in the health status is an important indicator.

\section{Conceptual framework}

\subsection{African Leadership and Health in Perspective}

The beginning of African leadership came with the massive support of the communistic and Marxist ideas by the people and this ideology came with the retreat of colonial rule as the colonial masters were associated with capitalist imperialism. The African socialism was then formed in the 1950s, spearheaded by Kwame Nkrumah, the first African president of Ghana. The socialism ideology was combined with indigenous traditions and the Marxist-Leninist model of one party rule with the argument of rapid modernization was the order of the day (Encyclopedia Britannica). Notable followers of this ideology included Julius Nyerere of Tanzania, Ahmed Sekou Toure of the Republic of Guinea, Ahmed Ahidjo of Cameroon, Antonio Agostinho Neto of Angola and Houphet Boigny of Cote d'Ivoire. These leaders initiated several infrastructural and development projects such as schools roads state owned enterprises and hospitals.

However, their one party state and dictatorship governance system begun to crumble as they faced various kinds of resistance and coup d'états, some of which were unsuccessful. Nkrumah was overthrown through coup d'état, Nyerere had to resign in 1985 as a result of fierce 
resistance to some of his hostile policies whilst Ahidjo had to resign on health grounds, Ahmed Sekou Toure, Antonio Agostinho and Houphet Boigny died whilst as leaders leading to various kinds of uprising as well as ethnic and religious tensions (Jorgensen and Bjornskov, 2015). There have been various leadership crises in Africa after independence as leaders who fought for this independence were often unwilling to relinquish power leading to coup d'états and uprisings.

After independence in Nigeria in 1960 the country had been under the control of tyrannical and autocratic military dictators for about 30 years before finally embracing democratic governance (Afegbua and Adejuwon, 2012). Zaire also never experienced Stable democratic governance as a result of despotic and tyrant leadership of Patrick Lumumba. Mobutu after terminating the government of Lumumba in 1960 acclaimed himself life President of Zaire and is known as one of the African leaders who overstayed their glorious days until was chased out of office. The present administration in Zaire is not ready to give room for popular elected leader (Afegbua and Adejuwon, 2012). In Zambia the ambition of President Kenneth Kaunda of becoming a life President was cut short after ruling for 21 years, from 1970-1991 when Federick Chiluba was popularly elected as President in the general election.

The political situation in Ghana had not been different, after independence in 1957 Kwame Nkrumah ruled until 1969 when his government was toppled. Afterwards Military rule was the order of the day for almost 20 years. Jerry Rawlings governed as a Military ruler from 1981 and changed to President after 12 years in power through a series of less-than-legitimate elections before handing over power to John Kuffour in 2001. Kamuzu Banda became head of state in Malawi in 1966 and proclaimed himself life president for the country and life chairman for is party amidst human rights abuses. It took the Amnesty International to alert the world on the frightening situation about the suppression being melted to the opposition in the country. 
In Kenya, Daniel Arap Moi became the leader after the death of President Jomo Kenyatta in 1977. He also ruled autocratically for years and rejected any reforms that could pave way for democratic governance in the country (Afegbua and Adejuwon, 2012). Similarly in Liberia, in 1980, Samuel Doe killed William Tolbert who had been in government since 1951 with President Tubmen in a bloody coup. Samuel Doe ruled for 10 years and turned Liberia into a personal courtyard until 1990 when he was brutally murdered by Prince Yormie Johnson version of rebel. The rebel version of Charles Taylor ruled the country in a tyrannical and despotic manner until recently when peace returned to Liberia and the country became the first African country to elect a female President in a general election.

In the Central African Republic, Emperor Jean Bokassa toppled the regime of President David Dacke in 1966 and refused to allow democratic governance to operate but being governed by his entire family. One country, whose independence did not follow the normal trend of the African socialism ideology and today remains a model of the development story is Botswana, under Sir Seretse Khama, a college degree graduate from Britain, and has since independence been one of the fastest growing economies in the world (Seddon, 2005), even as a landlocked country. Unlike most of the African countries that were left with a legacy of well laid institutions and infrastructure as well as resources, Botswana did not start out with advantageous conditions after attaining independence.

The political leadership in African has been parochial rather than nationalistic as it corruptly converts resources into projects of primitive accumulation of which (Agbaje and Roberts 2002) pointed out that "post-independence leaders in Africa not only personalized power but also privatized the state for the purpose of primitive accumulation, clientelism, repression and all forms of opposition. Instead of using the state for initiating development, African leaders utilized it as a vehicle for terrorizing the citizenry, thereby leading to the disengagement of the populace from the public realm.” The fundamental problem militating 
development in Africa is the poverty of leadership making it the key issue even in the process of democratization. Adeola (2007) argues that the history of great nations have been linked to visionary and purposeful leadership, such leaders have played significant roles in the socioeconomic development and political upliftment of their countries. According to him the absence of leadership to give a clear-cut ideology leads to the lack of orientation and commitment. The transitions and regime changes in Africa have been various and different African leaders have had different policies and commitments that affect growth and hence the health status of their citizens over the years. However, African leaders have realized the need to put in much effort at reducing if not eliminating the diseases that have plunged their countries and characterized them as death trap zones.

For the past two decades African leaders have had series of meetings, commitments and conventions among themselves and have made various declarations towards improving the health needs of their respective countries, some of which have not been met. These have given the cause to question the extent to which these leaders are committed to improving the health needs of their people. In 2001, in Abuja, Nigeria, African leaders met and considered AIDS an emergency on the continent and called for the mobilization of all sectors and pledged $15 \%$ of public spending for health. Since then health funding has risen, but has still not reached the level that the Abuja declaration promised. Only few member states (Liberia, Madagascar, Malawi, Rwanda, Togo and Zambia) have achieved the Abuja target of allocating $15 \%$ of public expenditure to health whilst a number of member countries (eg Djibouti, Ethiopia, Lesotho and Swaziland) are within the reach of $15 \%$ target with a vast majority not meeting this essential commitment (UNAIDS, 2015). According to the World Health Organization (WHO, 2014), only eight African countries are on track to meeting the Millennium Development Goals (MDGs)Algeria, Cape Verde, Egypt, Eritrea, Madagascar, Rwanda, Seychelles, and Tunisia whilst most African countries are achieving less than 50\% of the gains required to reach the goals by 2015 . Progress on improving maternal health (MDG 5) is particularly slow. 
Some countries have enacted some health policies that have been commended: Ghana's national health policy that exempts women from paying for delivery care in public, mission and private health facilities in 2004 of which a number of African countries have followed suit namely, Burundi, Burkina Faso and Kenya. The National Health Insurance policies of South Africa, Ghana, Tunisia and Kenya that have improved healthcare delivery in their respective countries and the free primary healthcare policy of Ethiopia making it possible for more than $85 \%$ of the population having access to primary healthcare. To advance toward the Roadmap's first pillar, a number of countries have begun to implement innovative AIDS financing measures intended to reduce dependence on external funders. Kenya and Zimbabwe now earmark a portion of domestic tax revenues for an AIDS Trust Fund, while countries including Benin, Congo, Madagascar, Mali, Mauritius, Niger, Rwanda, and Uganda have established special HIV levies on mobile phone usage and airfares. Taking a different approach, South Africa reduced its spending on antiretroviral medications by $53 \%$ by reforming its tender process to increase competition among suppliers (UNAIDS, 2013)

The allocation of public expenditure to the health sector is mainly for the reason that it has positive effects on the formation of quality human capital, which boost economic growth while promoting equity and reducing poverty. The productivity and benefit of spending on health will however depend among other things on how funds are allocated within the health sector. In the attempt to improve social welfare of citizens, many governments chose to change the composition and direction of public expenditure. Among other socioeconomic priorities, health issues is one of the issues at the forefront of the millennium Development Goals which is to reduce under five mortality rate by two-thirds by 2015; the fifth goal is reducing maternal mortality ratio by three-quarters by 2015, and the sixth is to try to reduce infection rates of HIV/AIDS, malaria, and other communicable disease associated with hygiene and environment. Health issues are therefore of very importance in the development agenda of Africa in meeting 
the MDGs and these to a large extent depend on leadership's commitment, which in effect depends on the wide range of resources including the personal characteristics of its leaders.

The above, and in the view that leaders can influence institutions as well as the allocation of resources towards the health sector through commitments, initiatives and self-interests, it is imperative that we investigate the extent to which the characteristics of African leaders and regimes affect the development of the health sector and hence the health status of its people, which is a very vital indicator for economic performance.

\subsection{Good Governance Policy and Health}

Improvement in the health status of every country has largely been linked to good governance (Kirigia and Kirigia, 2011). The United Nations Development Programme (UNDP, 1997) outlines five principles of good governance: legitimacy and voice (participation and consensus orientation), direction (strategic vision), performance (responsiveness, and effectiveness and efficiency), accountability (and transparency), and fairness (equity and inclusiveness, and rule of law). According to Kaufman et al (1999) the World Bank also has three clusters (with six domains) of governance that include: processes by which those in authority are selected and replaced (voice and accountability, and political instability and violence); ability of government to formulate and implement sound policies (government effectiveness and regulatory burden); and respect of citizens and the state for institutions which govern their interaction (rule of law and control of corruption). The World Health Report 2000 has six domains of stewardship and include: generation of intelligence, formulating strategic policy framework, ensuring tools for implementation (powers, incentives, and sanctions), building coalitions/partnerships, ensuring

fit between policy objectives and organizational structure and culture, and ensuring accountability. 
Siddiqi et al (2008) outline ten principles (and 22 domains) for assessing governance of the health system : strategic vision (long vision, comprehensive development strategy including health), participation and consensus orientation (participation in decision-making process, stakeholder identification and voice), rule of law (legislative process, interpretation of legislation to regulation and policy, enforcement of laws and regulations), transparency (transparency in decision making and resource allocation), responsiveness of institutions (response to population needs and to regional local health needs), equity and inclusiveness (equity in access to care, fair financing of health care, disparities in health), effectiveness and efficiency (quality of human resources, communication processes, capacity for implementation), accountability (internal and external accountability), intelligence and information (information generation, collection, analysis and dissemination), and ethics (principles of bioethics, health care and research ethics). The framework assesses each of the 22 domains along three levels (national, health policy formulation, and policy implementation).

Siddiqi et al (2008) framework has been acclaimed as the most comprehensive in assessing governance and health development (Kirigia and Kirigia, 2011). This is because the UNDP and that of the World Bank are very necessary but not sufficient for assessment of governance and health development whilst the WHO's six domains do not include external partnership for health, efficiency in resource allocation as well as macroeconomic (fiscal policy) and political stability. Siddiqi's, though comprehensive, also fails to include macroeconomic and political stability as a separate principle. These are very important factors in determining good governance and health development as successive governments may thwart previous government's comprehensive and result oriented health policies, improve upon or implement better policies that affect the health status of their citizens.

In this paper we include leader characteristics, regime transitions and fiscal policies through the allocation of resources, both public and private to the health sector to examine the extent to which these factors impact on the health status of their citizens. We choose infant 
mortality rates as a measure of health status because it does not take a longer period of time for changes to be observed whenever there is a change of leader and regime. We control for leader specific effects instead of country specific effects because different leaders have different characteristics and therefore may impact on outcomes differently and also changes in policy largely depend on the characteristics of the leader. Also leaders matter more in certain regimes as they have fewer constraints on the power that they exert (Jones and Olken, 2005). We are doing this because the significant negative impact of political and macroeconomic instability on health development has been starkly demonstrated in the diminished health indicators of the African countries that have undergone various forms of political and macroeconomic turmoil and these to a large extent have been attributed to the kind of political leaders and regimes Africa has had over the years

A lot of studies have shown that health interventions significantly improve health status (Banister and Zhang, 2005; Lensink et al, 2003; Bidani Ravallion, 1997; Cremieux et al, 1999; Chochrane et al, 1978). Using a cross sectional data Filmer and Prittchette (1999) observe that health spending reduces infant mortality and similar findings were made by (Musgrove 1996; Issa and Oattara, 2005). The above findings provide solid basis that health policy that ensures increases in the allocation of resources to the health sector have a positive effect in improving health status of that country. Leaders who therefore commit resources towards the improvement of the health sector with effective policies are likely to improve on the health status of their citizens but this to a large extent depend on the type of leader.

\subsection{Health Trends in sub-Saharan Africa}

Figures 1-4 present the graphical view of infant mortality rates, public and private health expenditure per GDP and life expectancy at birth for the sub-Saharan countries used for the study in 2010 whilst figures 5-7 presents the annual averages of these health indicators during 
the period of study (1970-2010). Of the 44 countries that were used for the study, almost half (21) had their 2010 infant mortality rates below the continent's average as shown in fig. 1. Interestingly, all these countries that had their infant mortality below the average also had their life expectancy below the average with the exception of Benin, Comoros, Liberia, Niger and Mauritania (fig. 2). Quite frightening was governments' commitments to investments in the health sector as 25 countries had their public health expenditure per GDP below the average. It is interesting to note that all the countries that had their infant mortality rates below the average also had their public health expenditure per GDP below average with the exception of Burundi, Burkina Faso and surprisingly, Lesotho which was ranked the highest in the public health expenditure per GDP as shown in fig.3.

The above on public health expenditure per GDP confirms WHO's report (WHO, 2014) that African governments' commitment to meeting the Millennium Development Goals (MDGs), especially of infant and maternal mortality rates has not been encouraging. Our observations suggest that governments that commit more resources towards investments in the health sector are able to reduce infant mortality rates, increase life expectancy and hence improve health status. Only few countries had their public health expenditure above the continent's average. Countries that had both public and private health (fig. 4) expenditures below the average include Equatorial Guinea, Ethiopia, Madagascar, Senegal, Benin, Mauritius, Mauritania, Democratic Republic of Congo, Central African Republic, Kenya, Gabon, Eritrea, Chad and Nigeria. Even though these countries' public and private health expenditures per GDP were below the average we observe that countries such as Eritrea, Gabon, Kenya, Mauritius, Senegal, Madagascar and Ethiopia had their infant mortality rates below the continent's average. These evidences suggest that perhaps, reducing infant mortality and improving the health status of the citizens depend not only on investments in the health sector. 
Fig 1: Infant mortality (2010)

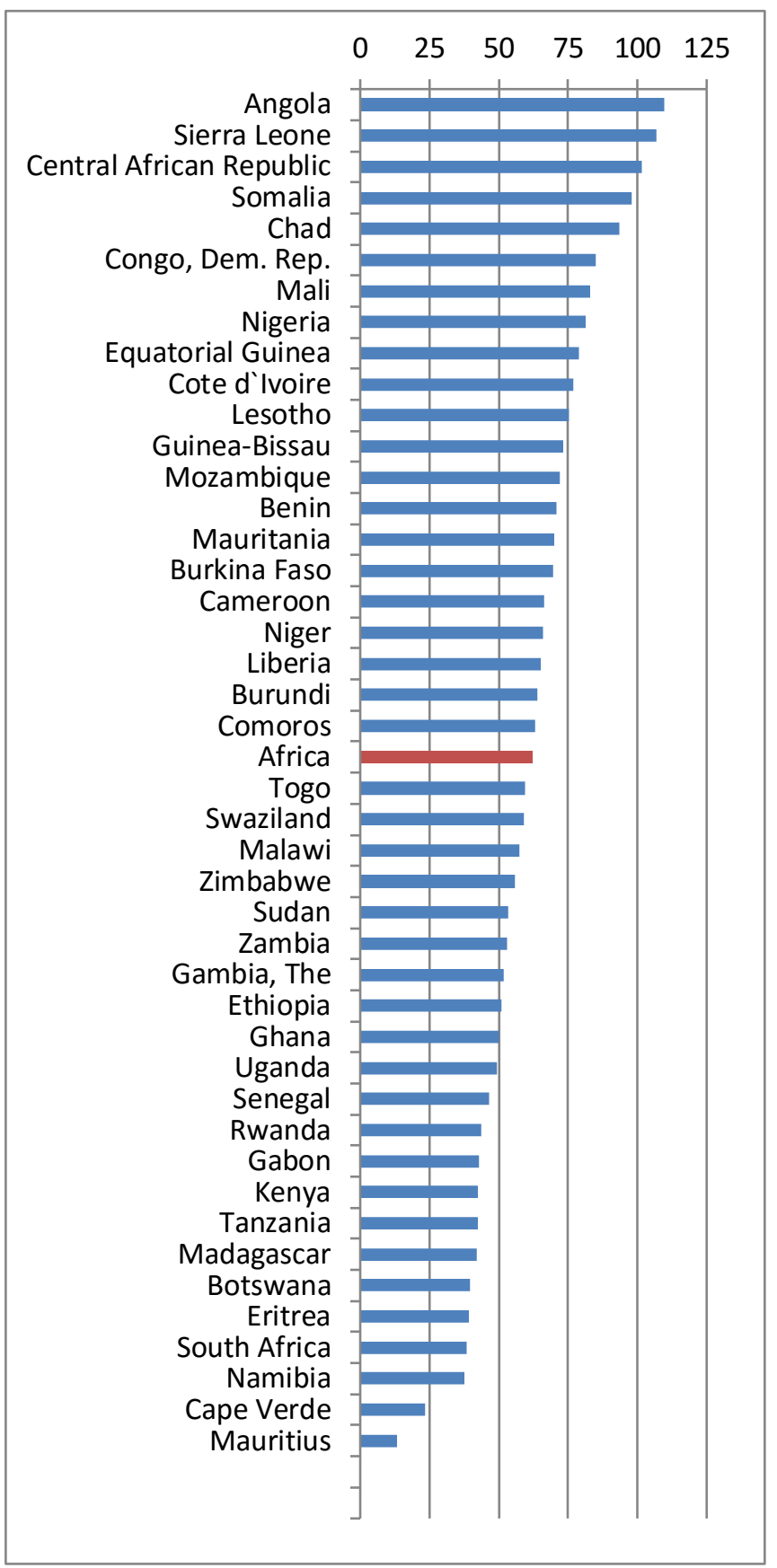

Fig 2: Life Expectancy (2010)

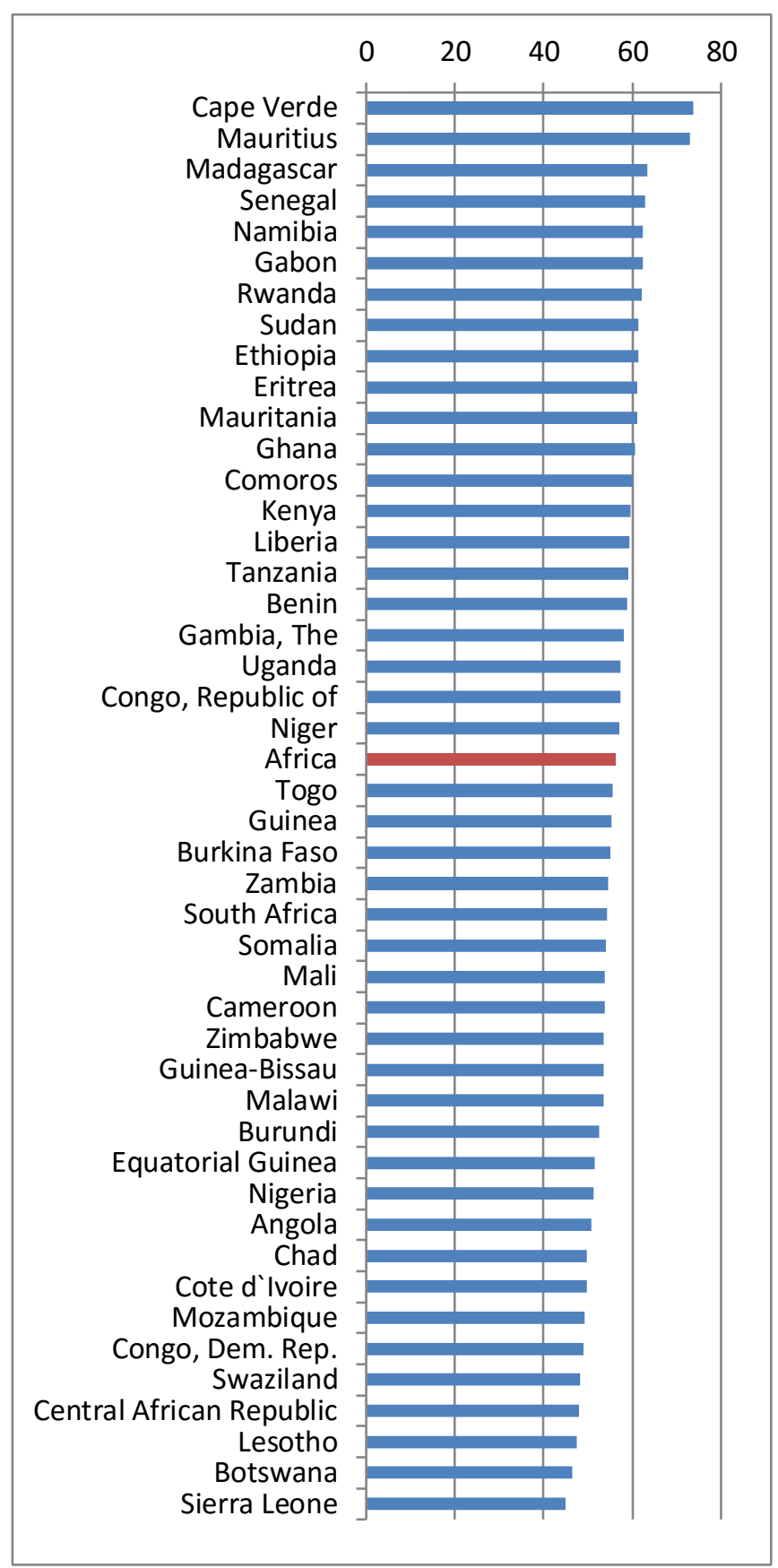


Fig 3: Public Health Expenditure per GDP (2010)

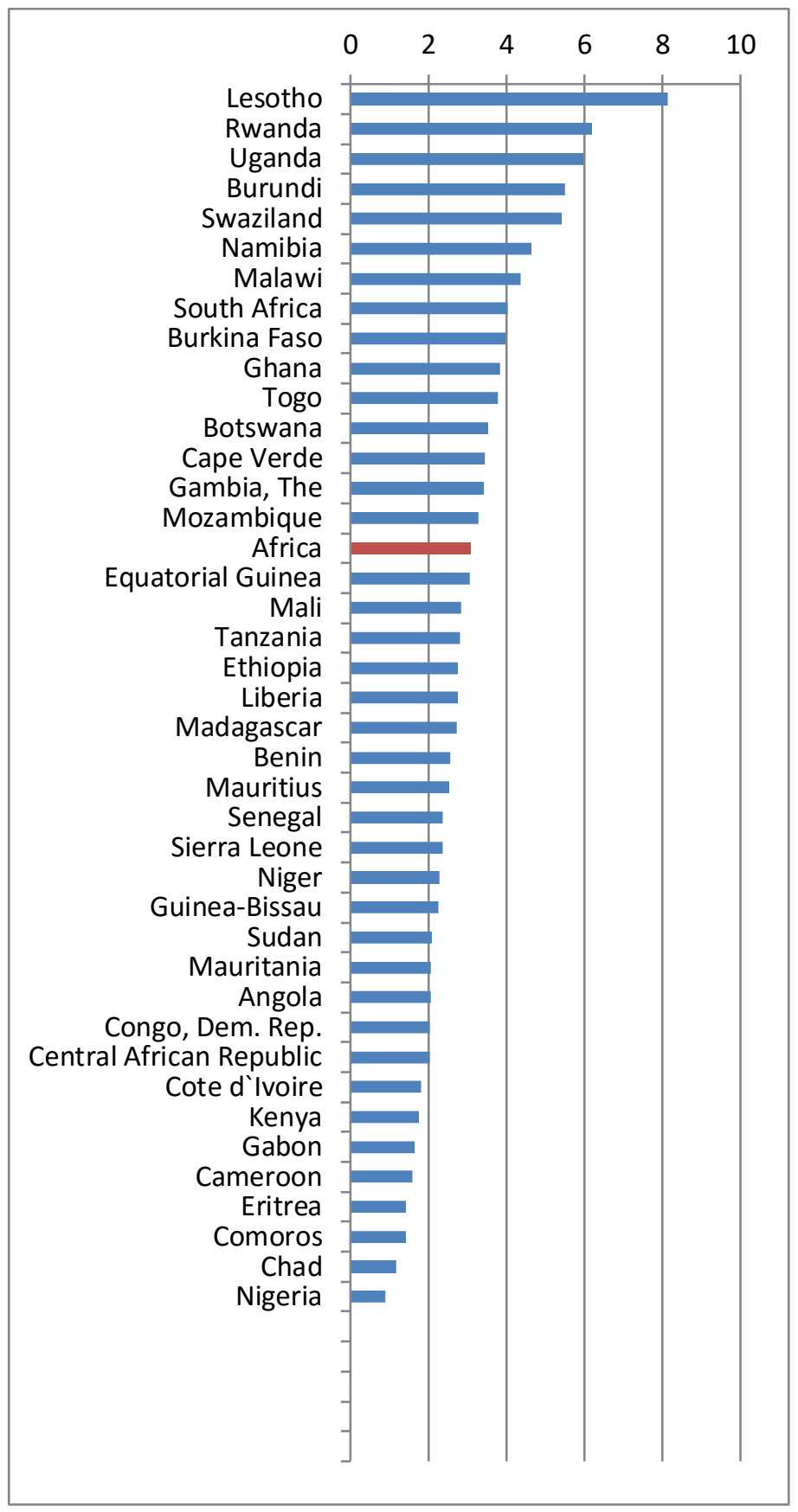

Fig 4: Private Health Expenditure per GDP (2010)

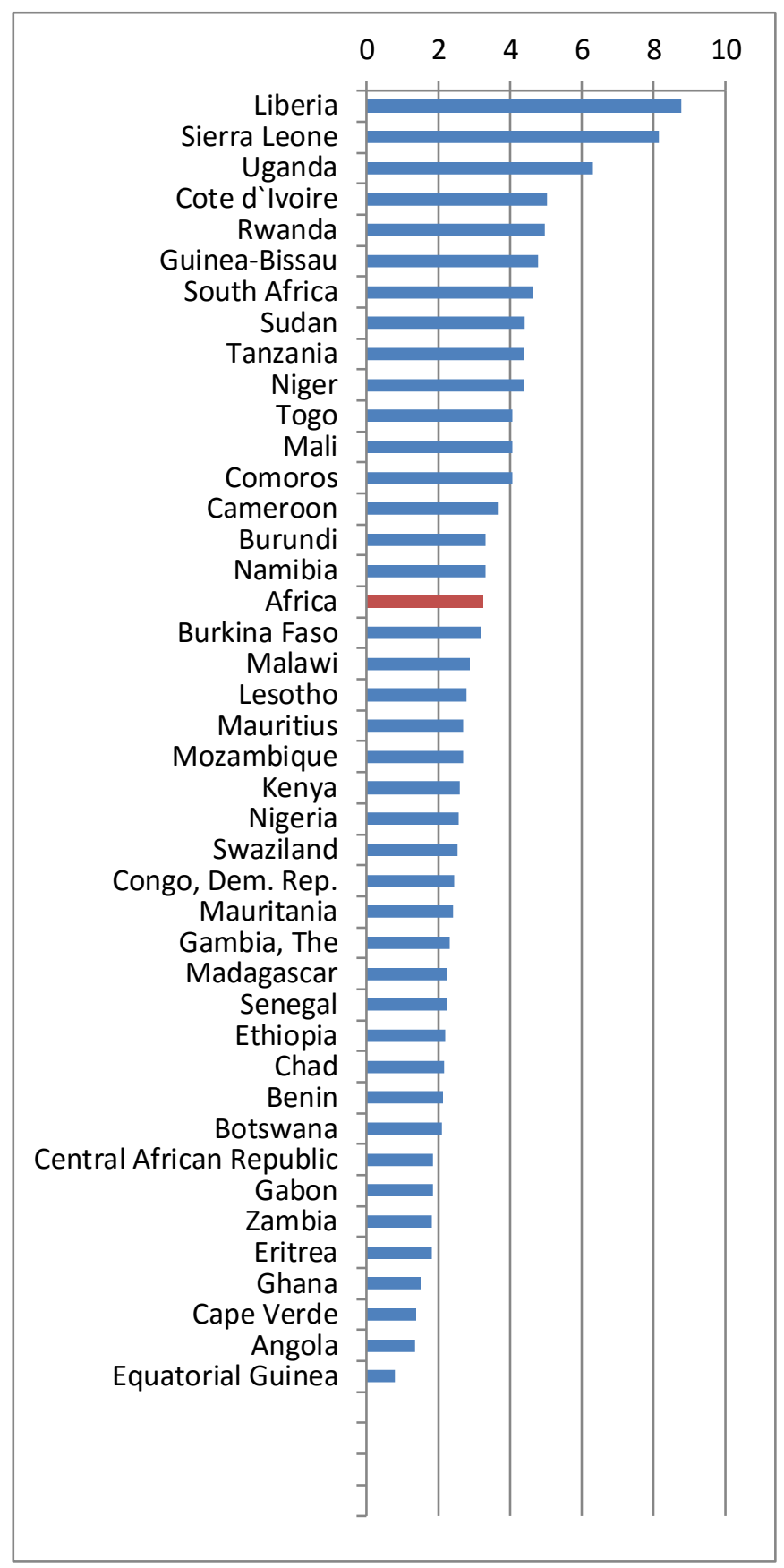


Fig.5 presents the graph of the annual averages of infant mortality rates between 1970 and 2010 for the sub-Saharan African countries used for the study. We observe that, between 1970 and 1990 infant mortality rates was reducing but after 1990 there was a sharp increase in the annual averages until in the mid-9os when it began to reduce again. This same phenomenon was observed in fig. 6 for the annual averages of life expectancy from 1970 to 2010. These may be largely attributed to the conflicts that occurred in some countries in the 1990s (see appendix 2) as well as the world economic recession in the 1990s that also affected Africa's economy. Fig.6 shows the graphical presentation of public vs private health expenditure per GDP between 1995 and 2010. Surprisingly, during this period private health expenditure was relatively higher than public health expenditure per GDP. This again supports WHO's report (WHO, 2014) that African governments' commitments to meeting the MDGs has been quite low. However, the graph in Fig.6 shows continuous rise of public health expenditure that is catching up with private health expenditure indicating a promising trend that public sector investments in the health sector is being continuously improved and hence health status would be improve to meet the MDGs in due course. 
Fig 5: Average Under-5 Infant Mortality in SubSaharian countries (1970-2010)

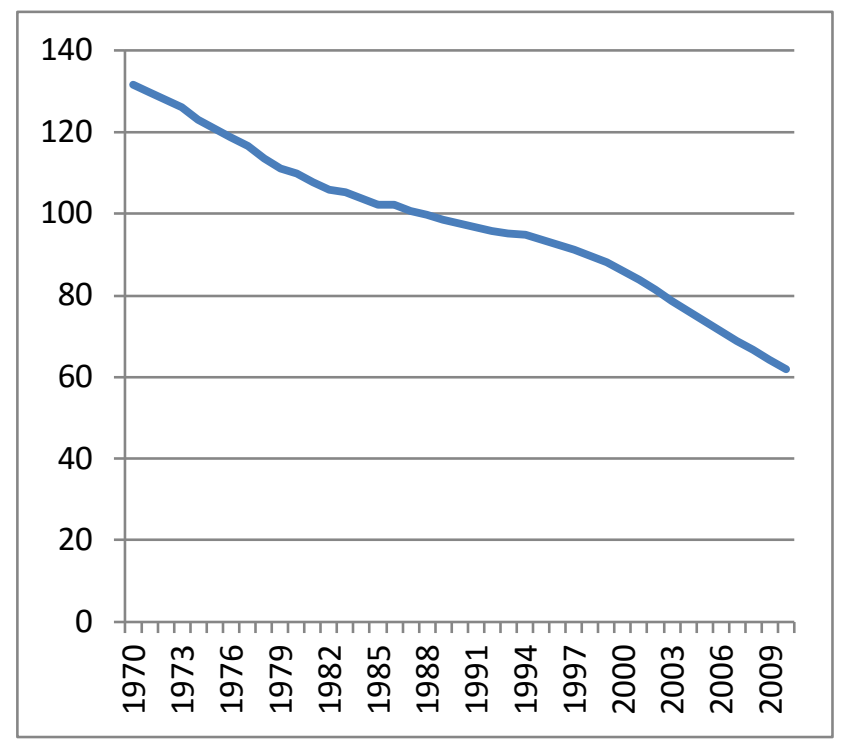

Fig 6: Average Life Expectancy in Sub-Saharian countries (1970-2010)

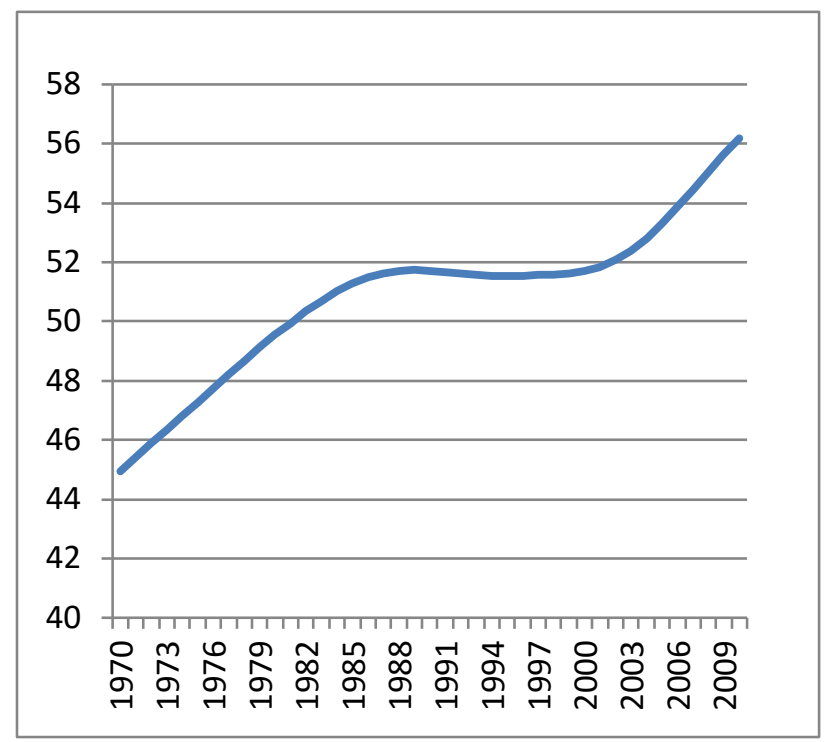

Fig 7 Average Public and Private Health Expenditure per GDP in Sub-Saharan countries (1970-2010)

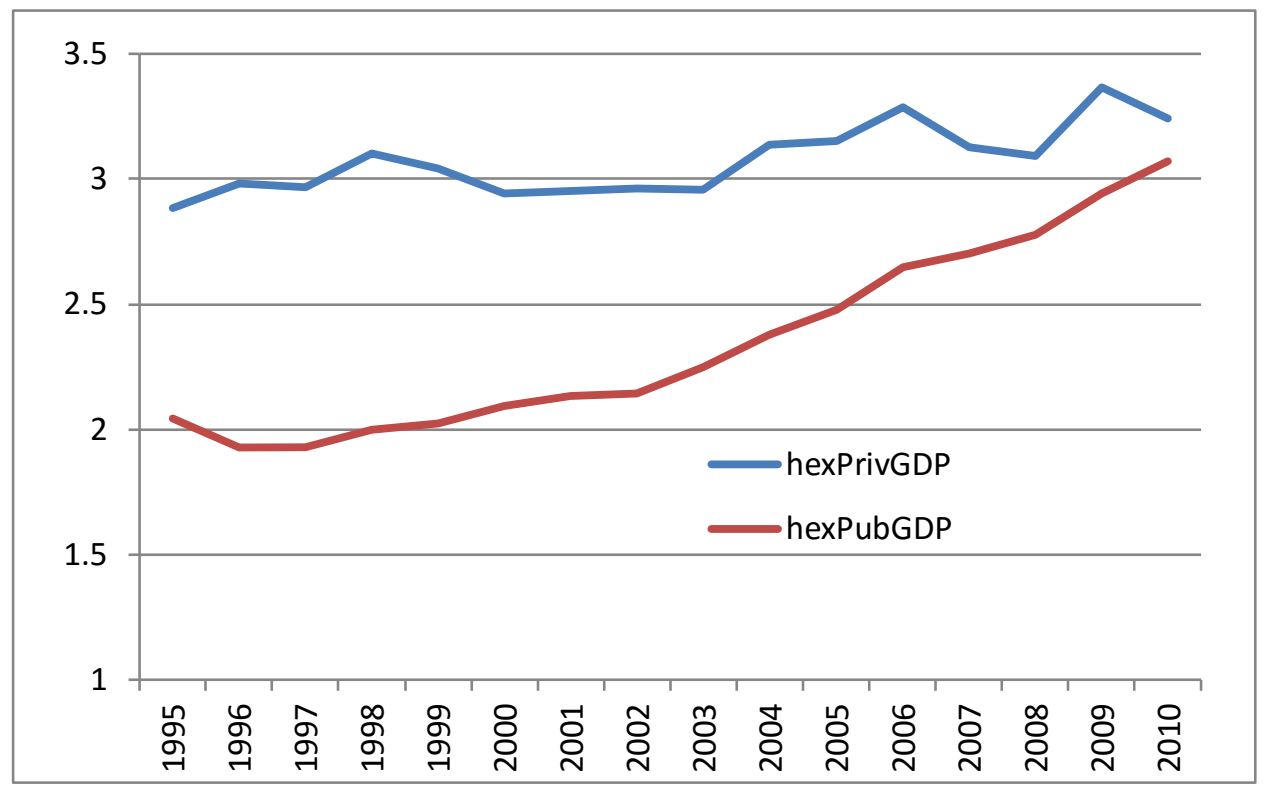




\subsection{Do Leader Characteristics and Regime Transitions Matter?}

Until recently the role of the leader in impacting on economic growth has had little attention in economic research. A growing literature connects personal traits of politicians with policy outcomes. One of such early research on leaders of countries is Jones and Olken (2005) who examines whether leaders matter. Using leader's transition where leader's rule ended by death, they observe a significant change in growth patterns as consequences of these transitions. They also find that leaders matter more in autocratic regimes and also in settings where the leaders have fewer constraints on their power.

Using a world data to determine the dynamics of political regimes and their impact on economic development Przeworski et al (2000) observe that economic development does not tend to generate democracies, but democracies are much more likely to survive in wealthy societies. They also observe that political instability affects growth only in dictatorships and that per capita income rises more rapidly in democracies because population increases faster under dictatorships. Using a dataset of 44 Sub-Saharan African countries from 1956-2010 Jorgensen and Bjornskov (2015) observe that, conditional on time, a leader with a social profession has a negative effect that persist up to 10 years after independence whereas lawyers and business profession have a positive effect up to 10 years after independence. They also observe a positive effect of a removal of a communistic leader both by political death and regime change on investment growth. Hayo and Neumeier (2012) observe in Germany that prime ministers tend to favor fiscal policies supporting the social class in which they are socialized. They also observe that governments led by prime ministers from a poor socioeconomic background spend significantly more on social security, education, health, infrastructure and public safety. Explaining why some countries democratize and others do not, using a world data between 1946 and 2004, Gift et al (2015) observe that leaders educated at Western Universities are more likely to democratize than other leaders because western education socializes leaders to prefer 
democracy and creates transitional linkages that alter the strategic calculus of democratization. They also observe that western educated leaders significantly and substantially improve a country's democratic prospects. Using a world data from 1960 to 2005, Siplimbergo (2009) observes that foreign-educated individuals promote democracy in their home countries but only if the foreign education is acquired in democratic countries. Diaz-Serrano and Perez-Reynosa (2013) show that more educated leaders raise citizens' education.

Osterloh (2010), in examining the impact of policy preferences of parties on economic growth for 23 OECD countries also observe a negative impact on growth for parties that support market interventions and a positive impact for parties which aim at setting incentives for business as well as those which promote technology and infrastructure. According to Aghion and Howitt, (2007) democracies tend to have much lower entry barriers than autocracies, because political accountability reduces the protection of vested interests, and entry in turn is known to be generally more growth-enhancing in sectors that are closely to the technological frontier. Brown et al (2011) observe that democratic governments, devote a higher percentage of their educational resources towards primary education and that they maintain higher absolute spending levels on education in the aggregate, thereby enhancing the prospects of human capital formation. They also find the same towards health and social security spending per capita. Their findings support that of Lake and Baum (2001), who observe that increases in democracy are significantly related to increases in the provision of public services, school enrolment and this is disproportionately large for countries that have undergone regime transition using a world data between 1970 and 1992. With regards to immunization against measles they observe that political change is associated with decreased rates of immunization against measles. Among countries that have undergone a maximum regime transition, the rate of measles immunization is more than 84 percentage points lower than among those with no regime change. 
On whether Africa's first leaders had persistent effect on the economic development, Jorgensen and Bjornskov, (2015) finds a strong and significant effect from ideology, profession and education. Bjornskov and Potrafke (2011) find political ideology affecting the degree of privatization after the collapse of communism in Central and Eastern Europe and therefore ideology affects growth. Further, Paldan (2013) finds that the cyclical path of growth in Africa correspond to the changes in development strategy where African socialism has been dominating one since 1965. Using a poll covering 92 countries in four year waves of 1990, 1995, 2000 and 2005 covering a total a total of 200 polls, Bjornskov and Paldam (2012), show that the west which, stands out as the most capitalist minded area of the world has been relatively successful for the last 3-4 centuries and, has reached an income level that is a great deal higher than most other countries and are able to form unions that are stable such as the EU.

\section{Hypothesis and a priori setting}

Hypothesis 1: democratic and political transitions of political leaders impact on the health of the people conditioned on growth

Good governance is a very important impetus for improved health status. The United Nation (UND, 1997) outlines five principles of governance and health development and indicate that legitimacy and voice (participation and consensus orientation), direction (strategic vision), performance (responsiveness, and effectiveness and efficiency), accountability (and transparency), and fairness (equity and inclusiveness, and rule of law). These are also characteristics and functions of democracy. Similar outlines are drawn by (Kaufman et al, 1999 and Siddiqi et al, 2008). Good governance therefore includes the ability of the leader to formulate and implement good policies for desired outcomes. Leaders who are committed to improving the health status of their citizens will therefore implement good health policies and ensure increased allocation of resources to the health sector to achieve the desired results. 
A change in political institutions alters the distribution of de jure political power, but creates incentives for investments in de facto political power to partially or even offset change in de jure political power. A change in transition, whether positive or negative, impacts on the growth of the economy and hence the health status of the citizens. Jorgensten Bjornskov (2015) observes a positive effect of a removal of a communistic leader both by death or regime change on investment growth. Diaz-Serrano and Perez Reynosa (2013) observe that transitions to more educated leaders increase the educational attainment of the population. According to Acemoglu and Robbinson (2002) countries with better institutions, more secure property rights and less distortionary policies will invest more in physical and human capital, and will use these factors more efficiently to achieve a greater level of income. Acemoglu and Robbinson (2002) further argues that institutions and ideology matter as they are witnessed in the divergent paths of North and South Korea, or East and West Germany, where one part of the country stagnated under central planning and collective ownership, while the other prospered with private property ownership and market economy. Osterloh (2010) finds a negative impact on growth for parties that support market interventions and a positive impact for parties that aim at setting incentives for business as well as those which promote technology and infrastructure. In democratic countries where private sector participation is acclaimed to be the engine of growth, both private and public health expenditures are likely to increase to affect the health status of such countries.

Bjornskov and Potrafke (2011) consider that the prospects for ideology-induced implementations may differentiate over the course of transition. Consequently, it is argued that within a window of opportunity in the first year of the transition, it is more likely for privatization and ideology-induced policies to occur. Transitions to democratic governance ensures stability and are more likely to attract private participation in all sectors include health that are likely to improve the health needs of the citizens. 
The type of democratic regime and that which allow free expression and market economy is likely to impact positively on the growth of the economy than one with autocratic regime. Researchers have argued that the greater accountability of democratic regimes whose poor performance can be sanctioned at the ballot box on a regular basis were more likely to outperform most authoritarian leaders who were able to stay in power regardless of their performance (Schedler et al., 1999). According to Jorgensen et al (2015) a coup gives a shock that breaks with the special interest. In a presidential and mixed democracy where leaders are voted into parliament to enact laws that affect the wellbeing of the people such regimes are likely to impact positively on the growth and the well-being of the people. Such regimes are likely to allocate a greater proportion of GDP to the health sector. Masaki and van de Walle (2014) find strong evidence that democracy promotes growth in Africa even though democratization in Africa has been relatively recent. On the influence of women representation in local council for instance, Chattopadhyay and Dufflo (2004) show that council members invest more in infrastructure that is directly related to the needs of their own gender. According to their findings women invest more and are likely to vote for the implementation of projects in the area of roads, water health and education. In democratic regimes where there is greater participation of women either as parliamentarians or council members and where women representation are ensured, the allocation of more resources towards health and welfare improvement will be championed and advocated for since women are known to be socially oriented.

We therefore expect that quality leaders and transitions from an autocratic leader to a democratic leader and hence democratic regimes would ensure the implementation of good health policies through the allocation of resources, both public and private that will lead to improved health status thorough reduction in infant mortality rates. We expect longer tenure of such transition would continue to have a positive effect on public and private health expenditures per GDP and a continuous reduction in infant mortality. 
Hypothesis 2: the age of the leader and the duration of presidency impacts on the health of the people conditioned on growth

According to Jorgensen and Bjornskov (2015) leaders who stay in power for a shorter period of time than the window of opportunity, might not have the same persistent effect as those staying in power beyond the window of opportunity. Oslon (1993) observe that leaders in power for a shorter period of time have had a negative effect on development, whereas leaders staying in power for longer period of time will have a longer and a more positive effect on development. These observations are true because it takes time for policies to achieve desired results. Policy analysts have often indicated that policies must often be assessed and reviewed from time to time for the overall desired results to be achieve and therefore policy effectiveness is dependent on time. This means that a leader must stay in power for a reasonable time period especially if policies initiated are to achieve the desired results. Transitions and tenure of the leader can change the allocation of health expenditure and this can affect the health status of the citizens, either negatively or positively. According to Jorgensen and Bjornskov (2015) as many African leaders have indulged in autocratic leadership styles and often stay in power for longer periods, this mechanism can also be relevant in relation to them. According to (Olson, 1993; McGuire et al, 1993) dictators care less about the future of the economy as they grow older and the probability of natural death increases. They in fact find evidence that an increase in the time horizon of a dictator leads to less investment in the productive capital and thereby less capital.

According to Dreher et al (2006) with a longer period in office, the leader might feel greater responsibility for all citizens, as compared to being interested mainly in approval by his former peers. The leader is also able to communicate with parliament and public and organize majorities due to learning effects. Such leaders are able to enact policies that have positive effects on their citizens such as health. Diaz-Serrano and Perez-Reynosa (2013) observe that age and tenure affect positively on the educational attainment of the population which is also a 
development indicator, like health. We expect longer periods of transitions from an autocratic leader to democratic leader to have a positive effect on the allocation of public and private health expenditure per GDP in ensuring reductions in infant mortality whilst we expect increase in age to also reduce infant mortality but to a limit in the increase in age. We therefore expect longer duration of tenure of a particular leader and increase in age beyond a desired limit to have dire consequences of the health status of the people.

\section{Data and variables}

To examine the impact of leader characteristics and regime transitions on the health status of the citizens and also assess the extent to which they affect fiscal policy with regards to health expenditures, we use annual panel data of up to 44 sub-Saharan African countries from 19702010. This period is selected based on the data available. Public and private health expenditures as a percentage of the GDP data are culled from the WHO Global Health Expenditure database. Infant mortality rates per 1000 live births data as well GDP per capita data were drawn from the World Bank database. These country data were drawn from these sources because they were the most comprehensive in terms of coverage. Data about health expenditures were available only from 1995. The independent variables of interest which are basically the leader characteristics and regime transitions were drawn from three different sources. In order to identify each primary ruler in each country we resort to the current version 4.1 of the Archigos data in Goemans et al (2009). This database identifies the effective ruler of each independent state and year based on the characteristics of the political system. We then draw our leader characteristics data also from Archigos data in Goemans et al (2009), whilst that on the regime transitions from Jorgensen and Bjornskov (2015).

Data on leader characteristics used as control variables comprised of the number of years in office of the leader before leaving office, either by death, coup d'état, ill health or exit through 
democratic elections, as year of tenure, and the age of the leader at the time he took office and in each year that he is in office. In order to assess the impact of changes in political regime we create two types of regime transitions; positive and negative. A positive regime change is pickedup by a dummy variable that takes the value 1 when a country transitions from a dictatorship leader (royal dictatorship, military dictatorship or civilian dictatorship) to a democratic leader (presidential democracy, mixed democracy or parliamentary democracy) whilst a negative regime change is picked-up by a dummy variable that takes the value 1 when a country transitions from a democratic leader (presidential democracy, mixed democracy or parliamentary democracy) to a dictator (royal dictatorship, military dictatorship or civilian dictatorship). For country control variables, the GDP growth rates, public and private health expenditures per GDP were used for the study. We did not include the gender, education and other characteristics of the leader that are constant over time. ${ }^{1}$ The reason for this is that we estimate a model with leader fixed-effects, therefore, any characteristic that do not vary over time is automatically dropped from the model. Also Sao Tome and South Sudan which are subSaharan African countries were excluded from the study because we did not have available data on most of the variables for the study.

In table 1, we show a descriptive statistical summary of the types of regime considered in our dataset. We observe that during the period used for the study dictatorship rule constitutes 84.1\% whilst democratic rule constitutes only $15.9 \%$. Out of this civilian dictatorship alone forms $45 \cdot 3 \%$ whilst military dictatorship forms $36.3 \%$ with royal dictatorship, constituting only $2.5 \%$. Presidential democracy forms 7.1\%, mixed democracy forms $6.2 \%$ whilst parliamentary democracy forms 2.6\%. Our data supports the observations made by Paldam (2013), that subSaharan African governance system has been dominated by dictatorship until in the 1990 and 2000 shen many of the countries embraced democracy. Africa's democratic governance is therefore a burgeoning one. With regards to regime transitions, Africa has had 149 periods of

\footnotetext{
${ }^{1}$ The period in which our research covers has only one female leader (Liberia) as president from 2006.
} 
transitions from a democratic ruler to a dictator (negative transitions) with only 47 periods of positive transitions (from a dictator to a democratic ruler). From Table 1 we also conclude that the number of democratic leaders under the period of study is 281 and constitutes $15.9 \%$ whilst dictatorship leaders are 1494 constituting 84.1\%. It must be emphasized that the African political governance has been dominated by dictatorship rule. 
Table 1: Descriptive statistics for Regime types

\section{Leaders' Regime}

\begin{tabular}{|c|c|c|c|c|}
\hline Royal dictatorship & A type of dictatorship regime & 46 & 2.5 & 0.159 \\
\hline Military dictatorship & A type of dictatorship by a military leader & 644 & 36.3 & 0.481 \\
\hline Civilian dictatorship & A type of dictatorship by a civilian leader & 804 & $45 \cdot 3$ & 0.498 \\
\hline Dictatorship (Total) & Putting all types of dictatorship as one & 1494 & 84.1 & 0.393 \\
\hline Presidential democracy & A type of leader in a democratic regime & 126 & 7.1 & 0.257 \\
\hline Mixed democracy & A type of leader in a democratic regime & 109 & 6.2 & 0.240 \\
\hline $\begin{array}{l}\text { Parliamentary } \\
\text { democracy }\end{array}$ & A type of leader in a democratic regime & 46 & 2.6 & 0.159 \\
\hline Democracy (Total) & Putting all types of democracies as one & 281 & 15.9 & 0.359 \\
\hline $\begin{array}{l}\text { Democratic to dictator } \\
\text { (negative transition) }\end{array}$ & $\begin{array}{l}\text { Transition from a democratic leader to } \\
\text { and autocratic leader }\end{array}$ & 149 & 8.3 & 0.272 \\
\hline $\begin{array}{l}\text { Dictator to Democratic } \\
\text { (positive transition) }\end{array}$ & $\begin{array}{l}\text { Transition from an autocratic leader to a } \\
\text { democratic leader }\end{array}$ & 47 & 2.6 & 0.158 \\
\hline
\end{tabular}


Table 2: Descriptive Statistics of Study Variables (in sample)

\begin{tabular}{|c|c|c|c|c|c|c|c|c|c|}
\hline \multirow[b]{2}{*}{ Variable } & \multicolumn{3}{|c|}{ Overall } & \multicolumn{3}{|c|}{ Democratic } & \multicolumn{3}{|c|}{ Dictatorship } \\
\hline & $\mathrm{N}$ & Mean & Std.Dev & $\mathrm{N}$ & Mean & Std.Dev & $\mathrm{N}$ & Mean & Std.Dev \\
\hline \multicolumn{10}{|l|}{ Country characteristics } \\
\hline $\begin{array}{ll}\text { Public } & \text { health } \\
\text { expenditure/GDP } & \end{array}$ & 397 & 2.092 & 0.930 & 116 & 2.166 & 0.786 & 281 & 2.061 & 0.983 \\
\hline $\begin{array}{l}\text { Private } \\
\text { expenditure/GDP }\end{array}$ & 407 & 2.993 & 1.478 & 116 & 3.00 & 1.88 & 291 & 2.989 & 1.287 \\
\hline $\begin{array}{l}\text { Under-5 mortality(per } 1000 \\
\text { live births) }\end{array}$ & 1374 & 101.93 & 34.733 & 185 & 80.031 & 36.736 & 1187 & $105 \cdot 337$ & 33.156 \\
\hline GDP per capita & 1395 & 643.831 & 926.143 & 184 & 767.85 & 956.576 & 1211 & 624.986 & 920.374 \\
\hline \multicolumn{10}{|l|}{ Leader characteristics } \\
\hline Age & 1495 & 54.686 & 11.93 & 190 & 59.647 & 10.217 & 1302 & 53.98 & 11.99 \\
\hline Leaders in office up to 4 years & 440 & $29.31(\%)$ & 0.455 & 107 & 56.315 & 0.4973 & 330 & 25.23 & 0.434 \\
\hline Leaders in office up to 8 years & 336 & $22.38(\%)$ & & 46 & 24.21 & 0.429 & 290 & 22.17 & 0.415 \\
\hline $\begin{array}{l}\text { Leaders in office beyond } 8 \\
\text { years }\end{array}$ & 725 & $48.30(\%)$ & & 37 & 19.4 & 0.397 & 668 & 52.59 & 0.499 \\
\hline
\end{tabular}


Table 2 presents the summary statistics of the variables for our study. It has been argued that democratic leaders tend to be socially inclined, committed to the health and social needs of its citizens and therefore allocate more resources towards social infrastructure in health and education. Our table shows that the average public and private health expenditure per GDP are greater under democratic lead exceeding the overall average, whilst autocratic averages falls a little below the overall averages. The most striking of them all is the infant mortality rates as we observe that the average infant mortality rate under democratic leadership is 80.03, far below the overall average of 101.93 whilst that under dictatorship governance is 105.34 which is higher than the overall average. These averages support the claims made by (Massaki and Robert, 2015, Kaufman et al, 1999, UNDP, 1997) that in democratic governance where there is increase in growth, rule of law, participation and consensus orientation, accountability and transparency, development is enhanced and health status improved. The observations made by Massaki and van de Walle (2015) that democracy brings about increase in growth is also supported as we observe an average GDP per capita to be higher under democratic leadership (767.85), higher than the overall average of 643.83 whilst that under dictatorship leadership is relatively lower (624.98) and below the overall average.

The average age of a democratic leader is 59.65 , higher than the overall average of 54.67 whilst that of a dictator is 53.98 , lower than the overall average. This is not surprising as according (Agbaje and Roberts, 2002), democratic leaders who are older are committed to the social needs of the people whilst the relatively younger dictator commits resources to his security and protection so as to stay in power for life. With regards to the number of years of tenure in office we find that $56.31 \%$ of democratic leaders stay in power up to the first 4 years, $24.21 \%$ do get the chance to rule for a second term (up to 8 years) and $19.4 \%$ beyond the second term. It must be emphasized that though some countries practice democratic governance their constitution allows a siting leader to continue to contest in elections even after a second term in office. The percentages for the tenure of up to 4 years and up to 8 years are relatively higher 
than the overall average but the percentage of democratic leaders staying in power beyond the 8 years is lower than the overall average of $48.30 \%$. Dictatorship leaders who stay up to 4 years constitute $25.23 \%$, those who stay for up to 8 years constitute $22.17 \%$, these percentages are lower than the overall average whilst $52.59 \%$ of dictators stay beyond 8 years which is higher than the overall average.

\section{Empirical Model}

In order to test our hypotheses, we consider the following empirical model:

$\Delta \mathrm{Y}_{i l t}=\alpha+\theta Y_{i l, t-1}+\beta T r_{i t}+\gamma C_{l t}+\tau X_{i t}+\mu_{l}+\varepsilon_{i l t}$,

where $Y_{\text {ilt }}$ can be the log of infant mortality rate, public health expenditure per GDP or private health expenditure per GDP in country $i$ at time $t$ when leader $l$ is in office; $\Delta$ is the difference operator. In order to capture potential state-dependence in our outcome variable $\left(\Delta \mathrm{Y}_{i l t}\right)$, that is, changes in the growth rates of our outcome variables depends on its initial value when a leader takes office, we include $Y_{i l, t-1}$, which is the lag of our outcome variable, the lag of the log of infant mortality rate, public expenditure per GDP or private expenditure per GDP. We estimate the determinants of the growth rate of our outcome variables and not the determinants in levels so that we can capture the contributions or the rate of change brought about as a result of a new leader and the change in the political regime; $T r_{i t}$ picks the transitions, the change of the regime of in country $i$ at time $t ; C_{l t}$ is a matrix containing the leader characteristics; $X_{i t}$ is a matrix containing a set of covariates controlling for country characteristics; $\mu_{l}$ is a leader-specific fixed effect; $\varepsilon_{i}$ is a time- varying error term, whilst $\theta, \alpha, \beta, \gamma$, and $\tau$ are a set of parameters to be estimated. 
Since we are interested in the impact of the characteristics of the leader, the inclusion in equation (1) of leader specific fixed-effects $\mu_{l}$ is very convenient. We control for leader's unobserved heterogeneity, which is not controlled for through the leader characteristics included in $C_{i t}$. We control for leader specific fixed-effects for the following reasons; leaders' characteristics vary significantly and therefore different leaders will impact on outcomes differently; we also control for leader specific effects due to the fact that changes in policy may not only be due to changes in transitions but also depend of the characteristics or ideology of the leader; according to Jones and Olken (2005) leaders matter more in certain regimes as they have fewer constraints on the power they exert. Also, since one leader can be in office only in one country, the leader- specific effects also absorb the country-specific effects. That is, controlling leader fixed-effects is also an indirect way of country specific effects. Our main coefficients of interest are $\beta$ and $\gamma$, which capture the effect of regime transitions (from dictatorship to democratic regimes and vice versa) and leader characteristics on the infant mortality rate and health policy with emphases on public or private health expenditure per GDP.

For the characteristics of the leader, the age and number of years in office (tenure) of the leader at the time he assumed office are considered. We consider a square polynomial of age and years of tenure to test if these two variables are inverted U-shaped on our outcome variables. Our econometric strategy to our empirical model is that the equation is differenced in order to remove the leader-specific effect $\mu_{l}$. However, by doing this strictly exogenous variables could become endogenous, in addition to non-strictly exogenous variables already present. By constructing our equation (1) therefore we lag the difference of our endogenous variable since it may be that the difference of other explanatory variables is correlated with the error term, which in turn creates a severe problem of endogeneity. Our core specification will therefore include not only correlated and heteroskedastic residuals, but also non-strictly exogenous and endogenous variables as covariates. The Newey-West corrected covariance method provides consistent 
estimates of standard errors in the presence of serial correlation and heteroscedasticity in the residuals. In this context however; severe identification problem is created due to the presence of endogenous covariates leading to inconsistent estimates.

Endogeneity constitutes one of the major concerns that have plagued the growth of democracy literature (Masaki and van de Walle, 2014). To tackle this problem, we resort to the Generalized method of moments (GMM) estimation method. We estimate our model by using a variant of the Arellano and Bond (1991) GMM estimator. Bond (2002), Blundell and Bond (1998) and Arellano and Bover (1995) show that often lags of the levels of these variables are poor instruments and suggest suitable conditions for fixing this problem. An alternative is to instrument endogenous and non-strictly exogenous variables with lags of their own first differences, instead of with lags of the variables in levels. This is the system GMM which is more efficient compared to the difference GMM since it uses moment conditions from the estimated first differences of the error term as well as the levels of the residuals. The method used here has both one-step and two-step versions of which we adopt the two-step version as it is the most efficient; the estimated variances tend to be biased downwards. To fix this, we apply the finitesample correction of the two-step covariance matrix proposed in Windmeijer (2005), otherwise standard errors would tend to be severely biased downwards. Similar to Masaki and van de Walle, (2014), we lag all leader and country characteristic variables and regime transition variables so as to eliminate the reverse effect of our dependent variables on our endogenous variables.

\section{Econometric results}

Panel data models account for the structure of the dataset by modelling the effects in the composite errors. A widely used panel data model, and thus in the literature on leader's effects, 
the fixed effects have been used repeatedly (Jorgensen and Bjornskov, 2015), which generally tend to be estimated by ordinary least squares (OLS). However, since the structure of our empirical model expressed in equation (1) is dynamic and hence the data generating process is an autoregressive process, using the OLS estimation method to estimate a fixed effects model will produce inconsistent estimates. However, a version of our equation (1) in levels can be used as a preliminary to examine the behaviour of the control variables on the outcome variables. It shall also be used to test the null hypothesis that leader characteristics do not matter, thus, $\mu_{l}=$ 0. Therefore, before to estimate equation (1) by the GMM method, we first estimate the following model resorting the fixed-effects method:

$Y_{i l t}=\alpha+\gamma C_{l t}+\tau X_{i t}+\mu_{l}+\varepsilon_{i l t}$

where left and right hand side in equation (2) contains the same variables as in equation (1), except the regime transition variables and the lag of the of the outcome variable.

Table 3 presents the results of the estimation of equation (2). The F-test results on the significance of the leader fixed-effects in all the three models are highly significant at $1 \%$ level. We therefore reject the null hypothesis of $\mu_{l}=0$ that leaders do not matter. We also observe that in democratic countries, GDP per capita correlates negatively with infant mortality as reported in column 1, though as one could expect, in countries with higher GDP both public and private investments as a share of the GDP is smaller (column 2 and 3). 
Table 3: Estimation of Equation (2). OLS Fixed-Effects Model

\begin{tabular}{|c|c|c|c|}
\hline VARIABLES & $\begin{array}{l}\text { Log(Infant } \\
\text { Mortality) }\end{array}$ & $\begin{array}{l}\text { Public Health } \\
\text { Expenditure/ } \\
\text { capita }\end{array}$ & $\begin{array}{l}\text { Private Health } \\
\text { Expenditure/ } \\
\text { capital }\end{array}$ \\
\hline Year of tenure & $\begin{array}{c}0.00495 * * * \\
(0.00131)\end{array}$ & $\begin{array}{c}0.0367 \\
(0.0255)\end{array}$ & $\begin{array}{l}-0.0424 \\
(0.0271)\end{array}$ \\
\hline Year of tenure (squared) & $\begin{array}{c}-4.05 e-05 \\
(3.39 e-05)\end{array}$ & $\begin{array}{c}-0.00146 * * * \\
(0.000528)\end{array}$ & $\begin{array}{c}0.00167 * * * \\
(0.000560)\end{array}$ \\
\hline Age & $\begin{array}{c}-0.0175 * * * \\
(0.000956)\end{array}$ & $\begin{array}{c}0.0625 * * * \\
(0.0239)\end{array}$ & $\begin{array}{c}0.0233 \\
(0.0254)\end{array}$ \\
\hline Log(GDP per capita) & $\begin{array}{c}-0.0597 * * * \\
(0.00727)\end{array}$ & $\begin{array}{c}-0.612 * * * \\
(0.0975)\end{array}$ & $\begin{array}{c}-0.339 * * * \\
(0.103)\end{array}$ \\
\hline Democracy & $\begin{array}{c}0.650 * * * \\
(0.209)\end{array}$ & $\begin{array}{l}-2.937 \\
(2.429)\end{array}$ & $\begin{array}{c}0.381 \\
(2.583)\end{array}$ \\
\hline Democracy xlog(GDPpc) & $\begin{array}{c}-0.0601 * * * \\
(0.0199)\end{array}$ & $\begin{array}{c}0.286 \\
(0.230)\end{array}$ & $\begin{array}{l}-0.0346 \\
(0.244)\end{array}$ \\
\hline Constant & $\begin{array}{c}6.094 * * * \\
(0.0813)\end{array}$ & $\begin{array}{c}4.981 * * * \\
(1.504)\end{array}$ & $\begin{array}{c}5.444 * * * \\
(1.598)\end{array}$ \\
\hline Observations & 1,213 & 397 & 407 \\
\hline R-squared & 0.627 & 0.216 & 0.064 \\
\hline Number of leader_n & 147 & 75 & 77 \\
\hline Adjusted R-squared & 0.574 & 0.0170 & -0.174 \\
\hline Ftest & 297.2 & 14.47 & 3.662 \\
\hline Prob $>$ F & 0 & 0 & 0.00156 \\
\hline
\end{tabular}

Standard errors in parentheses

$* * * \mathrm{p}<0.01, * * \mathrm{p}<0.05, * \mathrm{p}<0.1$

The results in column 1 also show that as the year of tenure increases infant mortality also increases, public health expenditure per GDP is reduced as shown in column 2, but private health expenditure per GDP is increased as indicated in column 3. The age of the leader is highly significant in reducing infant mortality rates and shows that, older leaders are socially oriented and enact policies that improve the health status of their citizens, though their health policies, that seek to allocate more public expenditure towards the health sector, is reduced when they 
are ageing as shown in column 2, whilst private investment in the health sector in turn increases.

In table 4, we report the results of the GMM estimation of equation (1). We first start commenting the results of the tests regarding the validity of the estimates, which are placed at the end of the table. The Hansen test for overidentifying restrictions replaces the Sargan test used in the original one-step Arellano-Bond estimator, since the Hansen test is robust to heteroscedasticity and autocorrelation. According to this test, the validity of the instruments is confirmed in all models, since $x^{2}$ statistic is not statistically significant for any of the models. We also show the results of the Arellano-Bond test for autocorrelation AR (1) and AR (2). Whereas AR (1) cannot be rejected in any of the models, at least at the 10\% level, the AR (2) which is used to detect autocorrelation is rejected in all models. These indicate that there is no serial correlation between the differenced variables used as instruments and the first differences of the residuals $\varepsilon_{i l t}$ implying that they are good instruments. The only exception to this general result is model 4, for which the null hypothesis of the absence of serial correlation is rejected.

Columns 1, 2 and 3 of table 4 report the results on the impact of leader characteristics and regime transitions on infant mortality, public and private health investments per GDP, by considering transitions from an autocratic leader to democratic leader, whilst columns 4, 5 and 6 report the results of the impact by considering the reverse transitions, i.e. from a democratic to an autocratic leader. Studies have linked leader characteristics to growth and development and the age and tenure of the leader have been found to have significant impacts (Jorgensen and Bjornskov, 2005; Olson, 1993; McGuire 1996, Dreher et al, 2006). The age of the leader, to a large extent determines how healthy and active the leader would be, to be able to monitor and assess the policies he has implemented whilst it also requires that the leader should stay in office for a desirable period within which policies enacted could be effectively promoted to ensure that it achieves the desired results. 
In columns 1 and 4, we observe that year of tenure of the leader as well as the age of the leader are u-shaped with infant mortality growth rate, which indicate as the leader grows older and stays in office for longer years his ability to influence health policy that ensures the reduction of infant mortality rates dwindles. These findings support our hypothesis 2. Similarly, in columns 2 and 3 we observe a U-shape for the age leaders on public and private health investment, whereas the effect of tenure in office is not statistically significant. That is, younger leaders are less prone to promote both public and private investments in health, while older leaders are more able to enact policies that have positive effects on their citizens such as health.

Our results also show that an increase of the GDP per capita reduces the infant mortality growth rate but reduces both the public and private investment in heath per GDP. This result do not necessarily imply that total monetary investment is reduced, but just that the increase in the health sector, if there was any, is proportionally smaller than the increase in the GDP.

We now examine the regimes and transitions to observe their impact on infant mortality rate and public and private investments in health. In column 1, we find that during the first four years of transition from a dictator to a democratic leader (first democratic mandate) infant mortality growth reduces respect to autocratic regime by $-3 \%(-0.133+0.106)$. The speed of reduction of the infant mortality growth rate increases during the fifth to eighth year of the transition (second democratic mandate) as infant mortality growth rate reduces further by almost $5 \%(-0.133+0.087)$. These results suggest that improving the health status of the citizens is a long run process and would be ideal if transitions from an autocratic leader to a democratic leader could be sustained for better and effective implementation of health policies for desirable outcomes.

We also observe that during the first four years of transition from a dictator to a democratic leader, public sector investment in health per GDP increases by about 0.7 percentage points $(0.396+0.333)$. However, during the second democratic mandate (years 5 to 8 after the 
transition) the investment in public health per GDP is reduced by -0.4 percentage points (0.3960.798). Perhaps, the reduction in public investment in the public health sector may be attributed to the fact that there were huge investments made in this sector during the first four years and the need to invest in other sectors during the following four years. Analogously, we observe an increases of 0.8 percentage points $(-0.868+1.685)$ in the investment in private health per GDP during the first four years of transition from a dictator to a democratic leader. In contrast, between the fifth and the eighth year after the transition the investment in private health is reduced by -0.87 percentage points. The above results show that both public and private health investments in the health sector are enhanced under democratic regime and transitions from dictatorship to democracy, it is therefore not surprising that infant mortality rates are reduced at an increasing rate compared to that under a dictator and transition from a democratic leader to and autocratic leader.

We focus now on the impact of the transition from democratic to autocratic regimes (columns 4 to 6). Results are quite revealing. During the first four years of transition from a democratic leader to a dictator, infant mortality growth rate increases by $4.2 \%$ (0.064-0.022) more than that of democratic regimes. This further worsens as infant mortality growth rate further increases at rate by $8 \%(0.064+0.015)$ higher after the $5-8$ years of this transition. The public investment in health per GDP is reduced by almost -2.1 percentage points during the first four years of transition from a democratic leader to a dictator compared to democratic regimes, while during the $5-8$ years of this transition public sector investment is reduced by more of -3 percentage points. The above results show a total neglect of the public health sector during the transitions from a democratic leader to a dictator as public sector investments in the health sector is reduced drastically. However, under this transition, private sector investment in the health sector is increased dramatically. During the first four years of the transition, investment in private health per GDP increases by almost 2 percentage points, while during the years 5-8 after the transition this increase is of about 1.2 percentage more than in democratic regimes. 
These results may account for the increases in the infant mortality rates, during and after transitions from a democratic leader to a dictator, as access to private health facilities are expensive and unaffordable to the majority of poor and the vulnerable in the African continent.

Improving upon the health and the wellbeing of the citizens by the leader to a greater extent depends on the characteristics of the leaders and how effective their fiscal policies, especially that of health is implemented. Effective health policy that will allocate much resource to the health sector to effectively execute its implementation is therefore very necessary. The results above, supports that of (Filmer et al, 1999; Lensink et al, 2003; Banister et al, 2005; Issa et al, 2005), that, increase in health investment spending increases the health status of citizens of democratic countries. The results also support to the outlines in assessing good governance of the health system by (Siddiqi et al, 2008; UNDP, 1997; Kaufman, 1999), that better health governance and policy outcomes include long vision, participation in decision making and consensus orientation, equity in access to care, quality human resources, fair financing of health care, political stability and rule of law, all of which are characteristics and functions of democratic governance. The above results confirm our hypothesis that democracy and transition from dictatorship to democratic rule improves the health status of the citizens whilst dictatorship and transitions from democratic rule to dictatorship brings about a decline in the health status of the citizens as infant mortality rates are increased. 


\section{Table 4: GMM Estimation for Determinants of Health Status and Health Investments in Africa.}

\begin{tabular}{|c|c|c|c|c|c|c|}
\hline VARIABLES & $\begin{array}{c}\text { (1) } \\
\text { Log(Infant } \\
\text { Mortality) }\end{array}$ & $\begin{array}{c}(2) \\
\text { Public Health } \\
\text { Exp. / GDP }\end{array}$ & $\begin{array}{c}\text { (3) } \\
\text { Private Health } \\
\text { Exp. / GDP }\end{array}$ & $\begin{array}{c}\text { (4) } \\
\text { Log(Infant } \\
\text { Mortality) }\end{array}$ & $\begin{array}{c}(5) \\
\text { Public Health } \\
\text { Exp. / GDP }\end{array}$ & $\begin{array}{c}\text { (6) } \\
\text { Private Health } \\
\text { Exp. / GDP }\end{array}$ \\
\hline $\log (\text { Infant mortality })_{\mathrm{t}-1}$ & $\begin{array}{l}-0.026^{* * *} \\
(0.000)\end{array}$ & & & $\begin{array}{l}0.001^{*} \\
(0.001)\end{array}$ & & \\
\hline (Pub. Health Exp/ GDP)t-1 & & $\begin{array}{l}-0.520^{* * *} \\
(0.012)\end{array}$ & & & $\begin{array}{l}-0.595^{* * *} \\
(0.019)\end{array}$ & \\
\hline$(\text { Priv. Health Exp/ GDP) })_{t-1}$ & & & $\begin{array}{l}-0.254^{* * * *} \\
(0.017)\end{array}$ & & & $\begin{array}{c}-0.246^{* * *} \\
(0.006)\end{array}$ \\
\hline$\Delta \log ($ GDP per cap.) & $\begin{array}{l}-0.008^{* * *} \\
(0.000)\end{array}$ & $\begin{array}{l}-0.341^{* * *} \\
(0.024)\end{array}$ & $\begin{array}{l}-0.517^{* * *} \\
(0.043)\end{array}$ & $\begin{array}{l}-0.011^{* * *} \\
(0.000)\end{array}$ & $\begin{array}{l}-0.396^{* * *} \\
(0.050)\end{array}$ & $\begin{array}{c}-0.358^{* * *} \\
(0.035)\end{array}$ \\
\hline Year tenure $t_{-1}$ & $\begin{array}{c}-0.003^{* * *} \\
(0.000)\end{array}$ & $\begin{array}{c}0.010 \\
(0.008)\end{array}$ & $\begin{array}{l}-0.013 \\
(0.009)\end{array}$ & $\begin{array}{c}-0.006^{* * *} \\
(0.000)\end{array}$ & $\begin{array}{l}-0.013 \\
(0.009)\end{array}$ & $\begin{array}{c}0.003 \\
(0.006)\end{array}$ \\
\hline Year tenuret-1 (squared) & $\begin{array}{l}0.000^{* * *} \\
(0.000)\end{array}$ & $\begin{array}{l}-0.000^{*} \\
(0.000)\end{array}$ & $\begin{array}{l}0.000 \\
(0.000)\end{array}$ & $\begin{array}{l}0.000^{* * *} \\
(0.000)\end{array}$ & $\begin{array}{l}-0.000 \\
(0.000)\end{array}$ & $\begin{array}{l}0.000 \\
(0.000)\end{array}$ \\
\hline Age $_{t-1}$ & $\begin{array}{l}-0.008^{* * *} \\
(0.000)\end{array}$ & $\begin{array}{l}-0.105^{* * *} \\
(0.008)\end{array}$ & $\begin{array}{l}-0.153^{* * *} \\
(0.024)\end{array}$ & $\begin{array}{c}-0.006^{* * *} \\
(0.000)\end{array}$ & $\begin{array}{l}-0.090^{* * * *} \\
(0.009)\end{array}$ & $\begin{array}{l}-0.135^{* * *} \\
(0.010)\end{array}$ \\
\hline Age $_{t-1}$ (squared) & $\begin{array}{l}0.000^{* * * *} \\
(0.000)\end{array}$ & $\begin{array}{l}0.001^{* * *} \\
(0.000)\end{array}$ & $\begin{array}{l}0.001^{* * * *} \\
(0.000)\end{array}$ & $\begin{array}{l}0.000^{* * *} \\
(0.000)\end{array}$ & $\begin{array}{l}0.001^{* * *} \\
(0.000)\end{array}$ & $\begin{array}{l}0.001^{* * *} \\
(0.000)\end{array}$ \\
\hline Democracyt-1 & $\begin{array}{l}-0.133^{* * *} \\
(0.000)\end{array}$ & $\begin{array}{l}0.396^{* * *} \\
(0.115)\end{array}$ & $\begin{array}{l}-0.868^{* * *} \\
(0.119)\end{array}$ & & & \\
\hline (Dicta-to-Democ 1-4yrs) $)_{t-1}$ & $\begin{array}{l}0.106^{* * *} \\
(0.001)\end{array}$ & $\begin{array}{l}0.333^{* * *} \\
(0.092)\end{array}$ & $\begin{array}{c}1.685^{* * *} \\
(0.158)\end{array}$ & & & \\
\hline (Dicta-to-Democ 5-8yrs) $)_{\mathrm{t}-1}$ & $\begin{array}{l}0.087^{* * *} \\
(0.001)\end{array}$ & $\begin{array}{c}-0.798 * * * \\
(0.101)\end{array}$ & $\begin{array}{c}0.129 \\
(0.119)\end{array}$ & & & \\
\hline Dictatorshipt $_{\mathrm{t}-1}$ & & & & $\begin{array}{l}0.064^{* * *} \\
(0.001)\end{array}$ & $\begin{array}{l}-0.059 \\
(0.045)\end{array}$ & $\begin{array}{l}-0.012 \\
(0.075)\end{array}$ \\
\hline (Democ-to-Dicta 1-4yrs) $)_{\mathrm{t}-1}$ & & & & $\begin{array}{c}-0.022^{* * *} \\
(0.001)\end{array}$ & $\begin{array}{l}-2.089^{* * * *} \\
(0.609)\end{array}$ & $\begin{array}{l}1.963^{* * * *} \\
(0.485)\end{array}$ \\
\hline (Democ-to-Dicta 5-8yrs) t-1 & & & & $\begin{array}{l}0.015^{* * *} \\
(0.001)\end{array}$ & $\begin{array}{l}-0.299^{* *} \\
(0.142)\end{array}$ & $\begin{array}{l}1.191^{* * *} \\
(0.206)\end{array}$ \\
\hline Constant & $\begin{array}{c}0.335^{* * *} \\
(0.004)\end{array}$ & $\begin{array}{c}3.779^{* * *} \\
(0.143)\end{array}$ & $\begin{array}{c}4.778 * * * \\
(0.707)\end{array}$ & $\begin{array}{c}0.097^{* * *} \\
(0.005)\end{array}$ & $\begin{array}{c}3.868^{* * *} \\
(0.176)\end{array}$ & $\begin{array}{c}3.737^{* * *} \\
(0.282)\end{array}$ \\
\hline Observations & 1,057 & 320 & 328 & 1,057 & 320 & 328 \\
\hline Number of leaders & 128 & 61 & 63 & 128 & 61 & 63 \\
\hline Leader effect & YES & YES & YES & YES & YES & YES \\
\hline
\end{tabular}




\begin{tabular}{lccc|ccc} 
Hansen Test (stat.) & 119.90 & 47.95 & 43.26 & 117.84 & 50.57 & 44.39 \\
Test AR(1) (z-stat.) & 1.85 & -3.03 & -1.78 & 2.38 & -3.13 & -1.91 \\
Test AR(2) (z-stat.) & 1.25 & 1.31 & 0.15 & 2.34 & 1.73 & 0.13 \\
\hline
\end{tabular}

Standard errors in parentheses ${ }^{* * *} \mathrm{p}<0.01,{ }^{* *} \mathrm{p}<0.05,{ }^{*} \mathrm{p}<0.1$ 


\section{Conclusions}

The success or otherwise of any country depends on the quality of its leaders and its political regime. Leadership characteristics and political regime are of essence in any human set up and it is tantamount to a stable polity and development. African growth and development path cannot be effectively studied without examining the quality of leadership, transitions and regimes in the decision making and the policy effectiveness that ensures growth and development. In this paper, we examine the importance of a country's leader's individual characteristics and the political regime transitions that brought the leader into power and how these affect the health status of their citizens using infant mortality rate as a measure. A unique dataset comprising of 44 sub-Saharan African countries spanning from 1970 to 2010 were used for the study. We control for leader fixed effects for the fact that; leaders can impact on outcomes in that leaders vary significantly that different leader's lead to different outcomes; the impact of leader transitions is large relative to events that occur in their countries. Again since one leader can be in office only in one country, the leader-specific effects also absorb the country specific effects. Lastly changes in policy may not only be due to changes in transitions but also depend on the leader characteristics

The overall results are suggestive of a democratic advantage in the process of promoting growth and the wellbeing of the citizens in contemporary sub-Saharan Africa, at least in the long run. We observe that both public and private investments in the health sector are enhanced during the periods of transition from dictatorship to democracy, whilst during the periods of transition from democratic rule to dictatorship, there is total neglect of public sector investments in the health that causes infant mortality to rise . It is therefore not surprising that there is reduction in infant mortality rates during transitions from an autocratic leader to a democratic leader and reduces relatively more when this transition prevails for relatively longer period ( 5 to 8 years). We also find that as leaders stay in office for a period of time infant 
mortality reduces at a faster rate but as they grow older and stay in office for relatively longefr period the rate at which infant mortality reduces slows down. these indicate that there is a limit to which the age and tenure of the leader can have a favourable impact on health policy outcomes and hence the health status of their citizens. Our results also suggest that the highest increase in infant mortality occurs in years 5 to 8 after the transition from a democratic ruler to a dictator.

Our data shows that public health expenditure per capita over the years, at least, during the period of years under study are far below that of private health expenditure per capita. This observation shows that public health policies in Africa that seek to inject resources into the health sector have not been encouraging. But the fact that democratic African leaders, at least, put much resource into the health sector compared to their fellow dictators, it is promising that democratic governance in Africa will lead to improvement in the health sector investments and hence the health status of their citizens. It is also incumbent on electorates to elect quality but not aged leaders who, will ensure that effective policies and hence resource allocation towards the health sector is increased, and monitoring enhanced to achieved desired results. African states, must desire for change through democratic rule, for better and quality leaders. However they must ensure that there is continuity in terms of effective policies implemented by former leaders as our results show that greater reduction in infant mortality rates and hence improvement in health status is a long process. In Africa, lots of projects and polices that would have brought about development in the respective countries are often abandoned when there is a change in power especially from one party to another party.

We do not contest that some authoritarian leaders may be investing in the health sector to ensure improvement in the health status of their citizens however, our results shows a clear evidence of a democratic advantage over autocracy, at least in Africa today. We therefore recommend that African countries must embrace and sustain democratic governance, channel 
more resources into the health sector, enact polices aimed at increasing investment in the health sector and improve access, as these will ensure an ovearall improvement in the health status of their citizens which is a very important means of meeting the other development goals 


\section{References}

Acemoglu, D., Johnson, S., Robinson, J. A., and Yared, P. (2005). From education to democracy? American Economic Review, 95(2), 44-49.

Acemoglu, D., Johnson, S. and Robinson, J. A. ( 2002). "Reversal of fortune: Geography and institutions in the making of the modern world income distribution”, Quar-terly Journal of Economics, 117, 1231-1294

Acemoglu, Daron, and James Robinson. (2006). Economic origins of dictatorship and democracy. Cambridge, UK: Cambridge University Press.

Acemoglu, D., Johnson, S. and Robinson, J. A.( 2005). "Institutions as the fundamental cause of long-run growth", in P. Aghion et S. Durlauf (eds.). Handbook of Economic Growth, (1A), 386-414

Adeola, G.L. (2007). "Politics and democratization process in Nigeria: The prevailing issues”, LASU Journal of Social Sciences, 6 (1 \& 2).

Afegbua. S.I. and Adejuwon. K.D. (2012). The challenges of leadership and governance in Africa. International Journal of Academic Research in Business and Social Science, 2 (9), 141-157

African Union. (2007). Africa health strategy, CAMH/MIN/5(III). Addis Ababa, Ethiopia Agbaje, D.O. and Roberts, Y. (2000). Meeting the challenge of sustainable democracy in Nigeria, Ibadan: NISER

Aghion, P. and Howitt, P. (2009). Economie de la croissance, Paris, Economica.

Aghion P., Durlauf, S.(2005) eds., 2005. Handbook of Economic Growth. North Holland, Amsterdam

Aghion, P., Alesina, A. and Trebbi. F. ( 2008). "Democracy, technology, and growth." in institutions and economic performance, ed. Elhanan Helpman. Cambridge, MA. Harvard University Press, 511-43. 
Alesina, A., Devleeshauwer, A., Easterly, W., Kurlat, S. and Wacziarg, R. (2003). "fractionalization", Journal of Economic Growth, 8, 155-194

Arellano, M. and Bover, O. (1995). Another look at the instrumental variable estimation of errorcomponents models. Journal of Econometrics, 68(1),29 - 51 .

Barro, R. J. (1991). "Economic growth in a cross section of countries", The Quarterly Journal of Economics, 106 (2), 407-443

Barro, Robert J. (1999). “Determinants of democracy.” Journal of Political Economy, 107(6), $158-83$.

Banister, J. and Zhang, X. (2005). China, economic development and mortality decline. World Development, 33(1), 21-41.

Bates, R.H. (1981). Markets and states in tropical Africa: the political basis of agricultural policies. Berkeley: University of California Press.

Besley, T., Montalvo, J. G. and Reynal-Querol, M. (1997). "Do educated leaders matter?, ” Economic Journal, 121(554), 205-208.

Besley, T., and Reynal-Querol, M. (2011). “Do democracies select more educated leaders?” American Political Science Review, 105 (3), 552-66.

Besley, T. (2005). Political selection. Journal of Economic Perspectives, 19(3), 43-6o.

Bidani, B. and Ravallion, M. (1997). Decomposing social indicators using distributional data. Journal of Econometrics, 77(1), 125-139.

Bjørnskov, C., (2005). “Does political ideology affect economic growth?”, Public Choice, $\quad$ 123, 133-146

Bjørnskov, C. and Potrafke, N. (2011). "Politics and privatization in central and eastern europe", Economics of Transisition, 19(2), 201-230

Bjørnskov, C. (2008). The growth-inequality association: government ideology matters. Journal of Development Economics, 87, 300-308 
Bjørnskov. C. and Paldam, M. (2012). "The spirits of capitalism and socialism. A cross-country study of ideology", Public Choice, 150, 469-498

Blundell, R. and Bond, S. (1998). Initial conditions and moment restrictions in dynamic panel data models. Journal of Econometrics, 87(1), 115 - 143.

Bond, S. (2002). Dynamic panel data models: a guide to micro data methods and practice. Portuguese Economic Journal, 1(2), 141-162.

Brown, D.S., and Wendy H. (2004). "Democracy and human capital formation: education spending in Latin America, 1980 to 1997." Comparative Political Studies, 37 (7), 842864 .

Caselli, F., and Massimo M. (2002). Bad politicians. Journal of Public Economics, 71(3), 829-53.

Carnes, N. and Noam L. (2015). "Rethinking the comparative perspective on class and representation: Evidence from Latin America.” American Journal of Political Science 59(1): 1-18.

Chattopadhyay, R. and Duflo, E. (2004).Women as policy makers: evidence from an India-wide randomized policy experiment,.Econometrica , 72(5),1409-1443.

Cochrane, A. L., St. Leger, A. S., and Moore, F. (1978), Health service input and mortality output in developed countries. Journal of Epidemiology and Community Health, 32(1),200-205.

Cremieux, P., Ouellette P., and Pilon C. (1999). Health care spending as determinants of health outcomes. Health Economics, 8, 627-639.

DFID. (2006). Conflicts trends in Africa, 1946-2004. A macro-comparative perspective. Areport prepared for the Africa conflict prevention pool (ACCP). UK

Diaz-Serrano, L., and Perez, J. (2013). Do more educated leaders raise citizens' education? IZA DP No. 7661. 
Deaton, A. (2003). Health, inequality and economic development. Journal of Economic Literature. XLI, 113-158

Dreher, A. (2005). "Does globalization affect growth? Evidence from a new index of globalization”. Thurgauer Wirtschaftsinstitut Research Paper Series No 6.

Dreher, A., Lamla, M. J., Lein, S. M. and Somogyi, F. (2009). "The impact of political leaders profession and education on reforms", Journal of Comparative $\quad$ Economics, 37, 169193

Duflo, Esther. (2004). Why political reservations? MIT, Mimeo.

Easterly, W. and Levine, R. (1997). “Africa's growth tragedy: policies and ethnic divisions”, The -Quarterly Journal of Economics, 112, 1203-1250

Encyclopedia Britannica, URL: http://www.britannica.com/

Englebert, P. (2000). 'Solving the mystery of the Africa dummy'. World Development, 28(10),1821-35.

Filmer, D. and Pritchett, L. (1999). The impact of public spending on health: does money matter? Social science and Medicine, 49, 1309-1323.

Gift, Thomas and Daniel Krcmaric. (2015). "Who democratizes? Western-educated leaders and regime transitions.” Journal of Conflict Resolution

Goemans, H. E., Gleditsch, K. S., and Chiozza, G. (2009). Introducing Archigos: A Dataset of Political Leaders. Journal of Peace Research, 46(2):269-283.

Gupta. I. and Mitra. A. (2004). Economic growth, health and poverty: an exploratory study for India. Development Policy Review. 22 (2), 193-206

Hayo, B. and Neumeier, F. (2012). Political leaders' socioeconomic background and fiscal performance in Germany, MAGKS Joint Discussion Paper Series, 41-2011.

Horowitz, M., McDermott, R. and Stam, A. C. (2005). “ Leader age, regime type, and violent international relations", The Journal of Conflict Resolution, 46 (5), 661-685 
International Finance Company Report (2012). The business of health in Africa. World Bank Group, Washington DC.

Issa, H., and Ouattara, B. (2005) The effect of private and public health on infant mortality rates: does the level of development matters?, May 2005. Available http://citeseerx.ist.psu.edu/viewdoc/download?doi=10.1.1.63.9133\&rep=rep1\&type=pdf

Jones, B. and Olken, B. (2005). "Do leaders matter? National leadership and growth since World War II," Quarterly Journal of Economics, 120(3), 835-864.

Jones, G. (2011). "National IQ and national productivity: The hive mind across Asia”. Asian Development Review, 28, 58-71.

Jong-A-Pin, R. and Mierau, J. O. (2013). "No country for old men: aging dictators and economic growth”, CEB Working paper, 11/o39

Jorgensen, M.A., and Bjornskov, C. (2015). Did Africa’s first choices matter? Growth legacies of leaders at independence. IFN working paper 1090. Research institute of economics

Kaufman, D., Kraay, A., and Zoido-Lobaton P. (1999). Governance matters policy research Working Paper, 2196. The World Bank, Washington, D.C.

Kirigia, M.J and Kirigia, G.D. (2011). The essence of governance in health development. International Archives of Medicine. 4(11), 1-13

Kodila-Tedika, O. (2014). Governance and intelligence: empirical analysis from African data. Journal of African Development, 16 (1), 83-96

Krieckhaus, J. (2006). 'Democracy and economic growth: how regional context influences regime effects'. British Journal of Political Science, 36(2), 317-40.

Lake, D.A., and Baum, M.A. (2001). "The invisible hand of democracy: political control and the provision of public services.” Comparative Political Studies, 34 (6), 587-621.

Lee, D. S., Moretti, E. and Butler, M. (2004). Do voters affect or elect policies? Evidence from the U.S. House. Quarterly Journal of Economics, 119(3), 807- 860.

Lee, Yu Jung. (2005). Gender, sanitation and political leadership in india. Unpublished peer 
reviewed $\mathrm{PhD}$ thesis. UCLA electronic thesis and dissertation.

Lensink,H., Hanmer, L., and White, H. (2003). Infant and child mortality in developing countries: Analyzing the data for robust determinants. Journal of Development Studies, 4O(1), 101-118

Masaki. T., and van de Walle. N. (2014). The impact of democracy on economic growth in subSaharan Africa, 1982-2012. WIDER Working Paper 2014/o57. United Nation University.

McGuire, A., D. Parkin, D. Hughes and K. Gerard (1993), "Econometric analyses of national health expenditures: can positive economics help to answer normative questions?", Health Economics 2, 113-126.

Mehlum, H., Moene, K. and Torvik, R. (2006). "Institutions and the resources curse", Economic Journal, 116, 1-20

Montalvo, J. G. and Reynal-Querol, M. (2005). "Ethnic diversity and economic development”, Journal of Development Economics, 76, 293-323

Musgrove, P. (1996). Public and private roles in health: theory and financing patterns. World Bank Discussion Paper No. 339.

Ndulu, B.J., and O’Connell, S.A. (1999). 'Governance and growth in sub-Saharan Africa'. The Journal of Economic Perspectives, 13(3): pp. 41- 66.

Osborne, M. J. and Slivinski, A. (1996). A model of political competition with citizencandidates. The Quarterly Journal of Economics, 111(1), 65-96.

Olson, M. (1993). Dictatorship, democracy, and development. The American Political Science Review, 87(3),567-76.

Olson, M. (1996). “Distinguished lecture on economics in government big bills left on the sidewalk: why some nations are rich, and others poor", Journal of Economic Perspectives, 10 (2), 3-24 
Paldam, M. (2013), "The cycle of development in africa a story about the power of economic ideas", forthcoming in: Christensen, B.J., Kowalczyk, C., eds., Globaliza-tion Conference Book. Springer, 2014, Earlier version published in Swiss Journal of Economics and Statistics, 147, 427-59

Pande, R. (2003). "Minority representation and policy choices: the significance of legislator identity." American Economic Review, 93 (4), 1132-51.

Poutvaara, P. and Thomas T. (2003). Candidate quality, un- published typescript.

Potrafke, N. (2012). “Intelligence and corruption”, Economics Letters, 114(1), $\quad 109-112$.

Przeworski, A. (2000). Democracy and development: political institutions and well-being in the world. Cambridge: Cambridge University Press.

Sachs, J.D., and Warner, A.M. (1997). 'Sources of slow growth in African economies'. Journal of African Economies, 6(3), 335-76.

Seddon, D. (2005), "A political and economic dictionary of Africa", Routledge

Siddiqi S, Masud T.I, Nishtar S, Peters D.H, Sabri B, Bile K.M., and Jama, M.A. (2008). Framework for assessing governance of the health system in developing countries: gateway to good governance Cairo: World Health Organization Regional Office for Eastern Mediterranean.

Spilimbergo, Antonio.( 2009). "Democracy and foreign education.”American Economic Review 99 (1): 528-43.

The Economist. (2012). The future of healthcare in Africa: A report by the economist intelligence unit. Geneva, Switzerland.

United Nations Development Programme. (1997). Governance of sustainable human development: a UNDP Policy Document. New York

UN.(2015). The millennium development goals report. United nations

van de Walle, N. (2001). African economies and the politics of permanent crisis 1979-1999. Cambridge: Cambridge University Press. 
Weede, E. and Kämpf, S. (2002). “The impact of intelligence and institutional improvements on economic growth”. Kyklos 55,361-380.

WHO. (2000). World health report: Health systems: improving performance. Geneva, Switzerland

WHO. (2010). The world health report: Health system financing: the Path to universal coverage. Geneva, Switzerland.

WHO.(2014). The African regional health report. WHO regional office for Africa.

Windmeijer, F. (2005). A finite sample correction for the variance of linear efficient two-step GMM estimators. Journal of Econometrics, 126(1), 25 - 51.

World Bank (2005): Education Statistics: http://devdata.worldbank.org/edstats/cd.asp 


\section{Appendix 1: Countries and Regime Periods}

\begin{tabular}{|c|c|c|}
\hline Country & Periods under Dictatorship & Periods Under Democracy \\
\hline Angola & $1970-2010$ & \\
\hline Benin & 1970-1990 & 1991-2010 \\
\hline Botswana & $1970-2010$ & \\
\hline Burundi & 1970-1992; 1996-2004 & $1993-1995 ; 2005-2010$ \\
\hline Cameroon & $1970-2010$ & \\
\hline Cape Verde & 1970-1989 & $1990-2010$ \\
\hline Central Africa Republic & 1970-1992; 2003-2010 & 1993-2002 \\
\hline Chad & 1970-2010 & \\
\hline Comoros & 1970-1989; 1995-2003 & 1990-1994; 2004-2010 \\
\hline Congo Dem. & $1970-2010$ & \\
\hline Congo Rep. & 1970-1991;1997-2010 & 1992-1996 \\
\hline Cote d'Ivoire & 1970-2010 & \\
\hline Equatorial Guinea & $1970-2010$ & \\
\hline Eritrea & 1970-2010 & \\
\hline Ethiopia & $1970-2010$ & \\
\hline Gabon & 1970-2010 & \\
\hline Gambia The Rep. & 1970-2010 & \\
\hline Ghana & 1972-1978; 1982-1992 & $1970-1971 ; 1979-1981 ; 1993-2010$ \\
\hline Guinea & 1970-20101 & \\
\hline Guinea Bissau & $1970-1999 ; 2003-2004 ; 2009-2010$ & 2000-2002; 2005-2008 \\
\hline Kenya & 1970-1997 & $1998-2010$ \\
\hline Lesotho & $1970-2010$ & \\
\hline Liberia & 1970-2005 & 2006-2010 \\
\hline Madagascar & 1970-1992; 2009-2010 & $1993-2008$ \\
\hline Malawi & 1970-1993 & $1994-2010$ \\
\hline Mali & 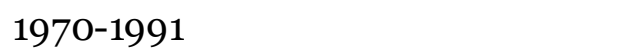 & 1992-2010 \\
\hline Mauritania & 1970-2006; 2008-2010 & $2007-2008$ \\
\hline Mauritius & & 1970-2010 \\
\hline Mozambique & $1970-2010$ & \\
\hline Namibia & $1970-2010$ & \\
\hline Niger & 1970-1992; 1996-1999; 2010 & 1993-1995; 2000-2009 \\
\hline Nigeria & $1970-1978 ; 1983-1998$ & 1979-1982; 1999-2010 \\
\hline Rwanda & 1970-2010 & \\
\hline Senegal & 1970-1999 & $2000-2010$ \\
\hline Sierra Leone & 1970-1997 & 1998-2010 \\
\hline Somalia & 19790-2010 & \\
\hline South Africa & $1970-2010$ & \\
\hline Sudan & 1970-1985; 1989-2010 & 1986-1988 \\
\hline Swaziland & $1970-2010$ & \\
\hline Tanzania & $1970-2010$ & \\
\hline Togo & $1970-2010$ & \\
\hline Uganda & $1970-1979 ; 1985-2010$ & $1980-1984$ \\
\hline Zambia & $1970-2010$ & \\
\hline Zimbabwe & $1970-2010$ & \\
\hline
\end{tabular}


Appendix 2: Conflicts in the sub-Saharan African Countries (1990-2004)

\begin{tabular}{llll}
\hline Dates & Countries involved & Description & Death toll \\
\hline $1986-1993$ & Nigeria & Communal Violence & 10000 \\
$1986-2004+$ & Uganda & Ethnic violence & 12000 \\
$1988 ; 1991 ; 1993^{-}$ & Burundi & $\begin{array}{l}\text { Ethnic violence; civil } \\
\text { violence; ethnic warfare }\end{array}$ & $10000 ; 1000 ; 100000$ \\
$200+^{+}$ & & Civil war & 100000 \\
$1998-2004$ & Somalia & International violence & 500 \\
$1989-1990$ & Mauritania-Senegal & Ethnic warfare; ethnic & $15000 ; 500000 ; 15000$ \\
$1990 ; 1994 ; 1994-$ & Rwanda & violence; ethnic warfare & \\
1998 & & Ethnic violence & 1000 \\
$1990-1995$ & Mali & Civil War & 40000 \\
$1990-1997$ & Liberia & Ethnic violence & 1000 \\
$1990-1997$ & Niger & Ethnic violence & 2000 \\
$1991-1993$ & Kenya & Civil, ethnic war & 25000 \\
$1991-2001$ & Sierra Leone & Casamance Separatism & 3000 \\
$1992-1999$ & Senegal & Ethnic violence & 1000 \\
1994 & Ghana & &
\end{tabular}

Source: (DFID, 2006) 